\title{
Basic Fibroblast Growth Factor: Receptor-Mediated Internalization, Metabolism, and Anterograde Axonal Transport in Retinal Ganglion Cells
}

\author{
Ian A. Ferguson, ${ }^{1}$ John B. Schweitzer, ${ }^{2}$ and Eugene M. Johnson, Jr. ${ }^{1}$ \\ 'Department of Pharmacology, Washington University School of Medicine, St. Louis, Missouri 63110 and ${ }^{2}$ Departments of \\ Pathology, Anatomy and Neurobiology, College of Medicine, University of Tennessee, Memphis, Tennessee 38163
}

Basic fibroblast growth factor (bFGF) was radiolabeled and used in axonal transport studies to determine whether certain neuronal populations express functional receptors for bFGF. Unlike ${ }^{125}$ |-NGF, ${ }^{125}$-bFGF was not retrogradely transported in the adult rat sciatic nerve or from iris to trigeminal ganglion or superior cervical ganglion. However, after intraocular injection of ${ }^{125}$-bFGF into the posterior chamber of the eye of adult rats, radioactivity was detected within the retinal ganglion cell projections. This radioactivity was localized to the ipsilateral optic nerve and in the contralateral lateral geniculate body and the contralateral superior colliculus by using autoradiographic techniques. Direct measurement of the radioactivity in dissected brain regions was used to study the process of ${ }^{125}$ |-bFGF uptake and transport by retinal ganglion cells. The uptake and transport were specific for biologically active bFGF since neither denatured, biologically inactive ${ }^{125} \mid-b F G F$ nor ${ }^{125} \mid$-NGF was taken up and transported. The uptake and transport of ${ }^{125}$-bFGF were saturable phenomena since they were blocked in the presence of excess, unlabeled bFGF. Wheat germ agglutinin, but not heparinase, blocked uptake and transport of ${ }^{125}$-bFGF, a finding that is consistent with the uptake being mediated by high-affinity bFGF receptors. Radioactivity from ${ }^{125}$ |-bFGF was transported in retinal ganglion cell axons in an anterograde direction at a maximum rate in excess of $1.7 \mathrm{~mm} / \mathrm{hr}$. No specific retrograde transport of bFGF to the retina was detected after ${ }^{125}$ I-bFGF was injected into the superior colliculus. The radioactivity from ${ }^{125}$ |-bFGF that accumulated in the superior colliculus was lost from this tissue with a half-life of about $22 \mathrm{hr}$. Autoradiography of proteins separated by SDS-PAGE demonstrated that ${ }^{125}$-bFGF was not substantially degraded in the retina after internalization within retinal ganglion cells. During anterograde transport, however, ${ }^{125}$ bFGF underwent limited proteolytic cleavage resulting in 3 prominent ${ }^{125}$-bFGF derivatives of molecular weights greater than $7000 \mathrm{Da}$. Although these were the major radioactive species recovered from the superior colliculus after intra-

\footnotetext{
Received Nov. 12, 1989; revised Dec. 4, 1989; accepted Jan. 29, 1990.

We thank Dr. Gary Fox of Amgen for generously providing the bFGF and Jennifer Columbo, Patricia Lampe, Patricia Osborne, and Ellen Looney for excellent technical assistance. This work was supported by NIH Grant NS 24679, NINDS Grants NS 25122 and NS 01230, and a grant from the American Paralysis Association. I.A.F. gratefully acknowledges support from a Fulbright Postdoctoral Fellowship.

Correspondence should be addressed to Ian A. Ferguson, Ph.D., Department of Pharmacology, Box 8103, Washington University School of Medicine, 660 South Euclid, St. Louis, MO 63110.

Copyright (C) 1990 Society for Neuroscience $0270-6474 / 90 / 072176-14 \$ 03.00 / 0$
}

ocular injection, some intact ${ }^{125}$-bFGF was also detected within the innervated target. These results indicate that retinal ganglion cells express high-affinity receptors for bFGF, that these receptors mediate the internalization of bFGF, that internalized bFGF undergoes limited proteolytic cleavage, and that bFGF and its derivatives are anterogradely transported to the lateral geniculate body and the superior colliculus. These data raise the possibility that bFGF or its derivatives may act as an anterograde trophic factor in the visual system, a system that is known to undergo anterograde transneuronal cell death.

Both acidic FGF (aFGF) and basic FGF (bFGF) are potent mitogens for a variety of cell types of mesodermal origin; they share 55\% amino acid sequence homology (Gospodarowicz et al., 1987) and interact with common cell-surface receptors (Neufeld and Gospodarowicz, 1986). aFGF and bFGF were first purified from brain tissue (Gospodarowicz et al., 1984; Bohlen et al., 1985) and have been purified from eye tissue (Gospodarowicz et al., 1987). Despite the presence of these FGFs in the CNS, the precise role of FGF in the nervous system remains unclear.

Arguments for (Gospodarowicz et al., 1987) and against (Barde, 1987) assigning FGF the status of a neurotrophic factor have been raised. FGF can induce neurotrophic responses: in PC12 cells both bFGF and aFGF induce a repertoire of responses similar to those induced by NGF (Togari et al., 1985), including the promotion of neuritic extension (Wagner and D'Amore, 1986; Rydel and Greene, 1987). bFGF is mitogenic in vitro for neuronal precursor cells from embryonic (E13) rat cortex (Gensburger et al., 1987). Neurons from fetal rat hippocampus (Walicke et al., 1986), fetal rat (Walicke, 1988) and newborn rat cortex (Morrison et al., 1986), ciliary ganglion (Schubert et al., 1987), fetal mesencephalon (Ferrari et al., 1989), and adult rat retina (Bahr et al., 1989) in tissue culture show enhanced survival and neuritic extension in the presence of bFGF. bFGF is reported to promote (Hatten et al., 1988) or not promote (Morrison et al., 1988) the survival in vitro of cerebellar neurons from postnatal rodents. bFGF also enhances the long-term survival of chick spinal cord neurons, including motor neurons, in tissue culture (Unsicker et al., 1987). bFGF prevents ontogenetic cell death in chick ciliary ganglia (Dreyer et al., 1989), and aFGF enhances neuritic outgrowth by dissociated retinal ganglion cells in vitro (Lipton et al., 1988). aFGF- or bFGF-impregnated Gelfoam implanted next to transected optic nerve reduces axotomyinduced degeneration of retinal ganglion cells in vivo (Sievers et al., 1987). Intraventricular infusion of bFGF (Anderson et al., 
1988) or implantation of bFGF-impregnated Gelfoam (Otto et al., 1989) can prevent some axotomy-induced changes in the medial septum.

The absence of antibodies or mRNA probes for the FGF receptor, however, has resulted in uncertainty as to whether neurons possess FGF receptors. Despite studies directed toward this question (Walicke and Baird, 1988), direct proof that neurons express functional receptors for bFGF in vivo is lacking. Accordingly, it has been argued (Barde, 1987) that the observed FGF effects on neurons may, in fact, be mediated by non-neuronal cells. Astrocytes in vitro can synthesize and respond in an autocrine fashion to bFGF (Ferrara et al., 1988). FGF is also mitogenic for oligodendrocytes in vitro (Eccleston and Silberber, 1985 ) and induces the synthesis of glial fibrillary acid protein in cultured astrocytes (Morrison et al., 1985).

A characteristic feature of most, if not all, growth factors is that the receptor-ligand complex is internalized after receptormediated binding. In NGF-responsive neurons, internalization of the NGF-NGF receptor complex is followed by axonal transport (Johnson et al., 1987). Given that bFGF provides trophic support for some neuronal populations in a manner analogous to NGF, we set out to determine whether bFGF would also be axonally transported in bFGF-responsive neurons. In this study, the axonal transport of radiolabeled bFGF was utilized to show that retinal ganglion cells express functional high-affinity receptors for $\mathrm{bFGF}$, that these receptors mediate the internalization of $\mathrm{bFGF}$, and that after being internalized, bFGF is proteolytically processed while it is being anterogradely transported. A brief account of some of these findings was recently reported (Ferguson et al., 1989).

\section{Materials and Methods}

Materials. Biologically active recombinant human basic $\left[\operatorname{ser}^{70}, \operatorname{ser}^{88}\right\rfloor$ fibroblast growth factor (bFGF; Fox et al., 1988) was provided by Amgen. Biologically inactive bFGF (XFGF) was produced by denaturing bFGF by an overnight dialysis against $0.1 \%$ acetic acid. The $2.5 \mathrm{~S}$ subunit of NGF was purified from adult male mouse submaxillary glands according to the method of Bocchini and Angeletti (1969). Na ${ }^{125}$ I was supplied by Amersham Corp. (Arlington Heights, IL). All other reagents, unless specified, were purchased from Sigma and were analytical reagent grade or better. Male Sprague-Dawley rats were used throughout and were supplied by Sasco, Inc. (Omaha, NE). Injections of radiolabeled ligands were made with a $5 \mu$ l Hamilton syringe, unless otherwise stated. Animals were handled according to the NIH guidelines. Statistical comparisons of data points were performed using the paired Student's $t$-test.

Preparation of 125 -labeled ligands. bFGF, XFGF, NGF, and cytochrome $c$ were iodinated to similar specific activities $\left(\sim 5 \times 10^{4} \mathrm{cpm} /\right.$ ng protein; percentage incorporation, $75-85 \%$ ) with $\mathrm{Na}^{125} \mathrm{I}$ and lactoperoxidase according to the method of Marchalonis (1969). For crosslinked receptor studies, ${ }^{125} \mathrm{I}-\mathrm{bFGF}$ was separated from unincorporated ${ }^{125}$ I on a heparin-affinity column (BioRad); the ${ }^{125} \mathrm{I}-\mathrm{bFGF}$ was eluted with $2 \mathrm{M} \mathrm{NaCl}$ after washing the gel with $500 \mathrm{~mm} \mathrm{NaCl}$ in $20 \mathrm{~mm}$ sodium phosphate buffer, $\mathrm{pH}$ 7.3. Labeled ligands with the following specific activities were used for axonal transport studies: $2600-2900$ $\mathrm{cpm} / \mathrm{fmol}$ for ${ }^{125} \mathrm{I}-\mathrm{NGF} ; 3200-4500 \mathrm{cpm} / \mathrm{fmol}$ for ${ }^{125} \mathrm{I}$-cytochrome c; $3100-4500 \mathrm{cpm} / \mathrm{fmol}$ for ${ }^{125} \mathrm{I}-\mathrm{bFGF}$; and $3600-4000 \mathrm{cpm} / \mathrm{fmol}$ for ${ }^{125} \mathrm{I}_{-}$ XFGF.

Crosslinked receptor experiments. This method was adapted from that described by Neufeld and Gospodarowicz (1986). Confluent FGF-receptor-bearing BHK-21 cells in $60 \mathrm{~mm}$ tissue culture petri dishes were washed twice with ice-cold L-15 medium. L-15 medium containing $0.1 \%$ gelatin and $10 \mathrm{ng} / \mathrm{ml}{ }^{125} \mathrm{I}-\mathrm{bFGF}$ or the same solution containing an additional 275 -fold excess of unlabeled bFGF was added to the cells and allowed to incubate for $1 \mathrm{hr}$ at $4^{\circ} \mathrm{C}$. 1-Ethyl-3-(3-dimethylaminopropyl) carbodiimide $\mathrm{HCl}$ (Pierce) was added to a final concentration of $50 \mathrm{~mm}$ and allowed to react for $30 \mathrm{~min}$ before being quenched by the addition of $0.1 \mathrm{~m}$ Tris/glycine, $\mathrm{pH} 7.5$. The cells were washed twice more with L-15 and solubilized for $30 \mathrm{~min}$ in $500 \mu \mathrm{l}$ of L- 15 medium containing $0.5 \%$ Triton $X-100$ and $2 \mathrm{~mm}$ phenylmethanesulfonyl fluoride. The cell suspension was centrifuged at $8000 \times g$ for 10 min to remove insoluble material. The supernatant was added to a tube containing $100 \mu \mathrm{l}$ of a $50 \%$ suspension of wheat germ lectin-Sepharose $6 \mathrm{MB}$. After mixing for $30 \mathrm{~min}$ at $4^{\circ} \mathrm{C}$, the gel was washed 3 times in PBS containing $0.5 \%$ Triton X-100. Then $100 \mu \mathrm{l}$ SDS treatment buffer ( $2 \%$ SDS, $2.5 \%$ 2-mercaptoethanol, $10 \%$ glycerol, $0.004 \%$ bromophenol blue, $62.5 \mathrm{~mm}$ Tris- $\mathrm{HCl}), \mathrm{pH} 6.8$, was added to the gel, heated in boiling water for $5 \mathrm{~min}$, and electrophoresed on $7 \%$ polyacrylamide gels (Laemmli, 1970). The gels were stained with Coomassie blue and dried. Autoradiograms were made with Kodak X-Omat AR film with a Dupont Cronex lightning-plus intensifying screen at $-70^{\circ} \mathrm{C}$

Retrograde transport of ${ }^{125}$ I-labeled ligands. Adult rats $(350-450 \mathrm{gm})$ were anesthetized with chloral hydrate $(350 \mathrm{mg} / \mathrm{kg})$; the right sciatic nerve was exposed and ligated at midthigh. Five microliters of freshly prepared ${ }^{125}$ I-NGF, ${ }^{125}$ I-bFGF, ${ }^{125}$ I-XFGF, or ${ }^{125}$ I-cytochrome c (about $8 \times 10^{6} \mathrm{cpm} ; 80 \mathrm{ng}{ }^{125}$ I-labeled ligand) were injected into the right foot pad and lower leg muscles ( 5 sites, $1 \mu \mathrm{l} / \mathrm{site}$ ) and into the anterior eye chamber of the right eye, without prior separation of free ${ }^{125} \mathrm{I}$ from protcin-bound ${ }^{125} I$. Fiftecn hours later, rats were decapitated under ether anesthesia, and the superior cervical ganglia, trigeminal ganglia, and ligated and unligated (contralateral) sciatic nerves were removed. Radioactivity in ganglia and in $3 \mathrm{~mm}$ lengths of sciatic nerve immediately proximal and distal to the ligation and in the contralateral side was determined in a gamma counter (Beckman). In separate experiments, newborn Sprague-Dawley rats were anesthetized by hypothermia and the right sciatic nerve exposed and ligated at midthigh. Three microliters of freshly prepared ${ }^{125} \mathrm{I}-\mathrm{NGF},{ }^{125} \mathrm{I}-\mathrm{bFGF},{ }^{125} \mathrm{I}-\mathrm{XFGF}$, or ${ }^{125}$ I-cytochrome $\mathrm{c}$ were injected into the right foot pad ( 3 sites, $1 \mu \mathrm{l} / \mathrm{site})$. Twelve hours later, the rat pups were decapitated, and the radioactivity in $3 \mathrm{~mm}$ lengths of sciatic nerve immediately proximal and distal to the ligation. was determined.

Intraocular injections of ${ }^{25}$ I-labeled ligands. Male rats (average weight, $300 \mathrm{gm}$ ) werc ancsthetized with ether and $5 \mu \mathrm{l}$ of freshly prepared ${ }^{125} \mathrm{I}-$ NGF, ${ }^{125} \mathrm{I}-\mathrm{bFGF}$, ${ }^{125} \mathrm{I}-\mathrm{XFGF}$, or ${ }^{125} \mathrm{I}$-cytochrome $\mathrm{c}$ (about $8 \times 10^{6} \mathrm{cpm}$; $80 \mathrm{ng}{ }^{125}$ I-labeled ligand) were injected into the posterior eye chamber of the right eye, without prior separation of free ${ }^{125} I$ from protein-bound ${ }^{125} \mathrm{I}$. At various times after injection, the rats were anesthetized with ether and decapitated. The eyes, optic nerves (from eye to chiasm), superior colliculi, and lateral geniculate bodies were dissected from both contra- and ipsilateral sides and the radioactivity determined. In other experiments, unlabeled bFGF, wheat germ agglutinin ( $75 \mu \mathrm{g} / \mathrm{eye})$, heparinase $\left(1.5\right.$ Units/eye), or heparin $(5 \mu \mathrm{g} / \mathrm{eye})$ was injected with ${ }^{125} \mathrm{I}$ bFGF.

Injections into the superior colliculus. Male rats (275-325 gm) were anesthetized with chloral hydrate and mounted in a stereotaxtic apparatus (Kopf). One microliter of freshly prepared ${ }^{125} \mathrm{I}-\mathrm{bFGF}$ or ${ }^{125} \mathrm{I}-\mathrm{bFGF}$ plus 1000 -fold excess of unlabeled bFGF (total of $2 \times 10^{6} \mathrm{cpm}$ or 30 ng ${ }^{125} \mathrm{I}-\mathrm{bFGF}$ ) was injected from a glass pipet (tip diameter, $50-100 \mu \mathrm{m}$ ) over $30 \mathrm{~min}$ by using a micromanipulator. Injections were made unilaterally into the optic nerve layer of the superior colliculus with the stereotaxic coordinates $-2.5 \mathrm{~mm}$ lambda, $1.0 \mathrm{~mm}$ lateral, $3.5 \mathrm{~mm}$ from the skull surface (Paxinos and Watson, 1982). Twenty-four hours later, rats were anesthetized with chloral hydrate and perfused transcardially with PBS followed by $4 \%$ paraformaldehyde, $0.5 \%$ glutaraldehyde, $15 \%$ saturated picric acid in $0.1 \mathrm{~m}$ sodium phosphate buffer, $\mathrm{pH} 7.2$. The eyes were freed of all attached muscle and tissue; the superior colliculi were dissected. Their radioactivities were determined in a gamma counter. In other experiments, $30 \%$ HRP in PBS containing $0.1 \%$ dimethyl sulfoxide was injected into the superior colliculus and the eyes were removed as described above. The retinas were separated from the sclera and rinsed for $1 \mathrm{hr}$ in L-15 medium. HRP deposits were visualized by $10 \mathrm{~min}$ incubation in Tris-HCl-buffered saline containing $0.05 \% 3,3^{\prime}$ diaminobenzidine $\mathrm{HCl}$ and $0.01 \%$ hydrogen peroxide at room temperature. Retinas were cryoprotected in PBS containing 20\% sucrose, embedded in Tissue-Tek O.C.T. (Miles Scientific, Naperville, IL), and frozen on dry ice. Frozen cross sections of the retinas were cut at 15 $\mu \mathrm{m}$, dehydrated with a graded series of alcohol, cleared in toluene, and mounted in Pro-Tex (Baxter Scientific Products, McGaw, IL).

Autoradiography. Rats injected intraocularly in the posterior eye chamber 18 and $48 \mathrm{hr}$ previously with ${ }^{125} \mathrm{I}-\mathrm{bFGF}$ or ${ }^{125} \mathrm{I}-\mathrm{XFGF}$ were anesthetized with chloral hydrate and perfusion-fixed transcardially with $4 \%$ paraformaldehyde, $0.5 \%$ glutaraldehyde, and $15 \%$ saturated picric acid in $0.1 \mathrm{~m}$ sodium phosphate buffer, $\mathrm{pH} 7.2$. Fixed brains were cut into $5 \mathrm{~mm}$ coronal blocks and embedded in paraffin. Serial coronal 
sections, 6-8 $\mu \mathrm{m}$, were cut, and every 10th section through areas of interest mounted, dried, deparaffinized, and coated with Kodak NTB-2 emulsion. The slides were developed after being exposed for $30 \mathrm{~d}$ at $4^{\circ} \mathrm{C}$. Sections were counterstained with toluidine blue and mounted in Pro-tex.

SDS-PAGE autoradiography of brain tissue. Optic nerves and superior colliculi were dissected from animals injected in the posterior eye chamber with ${ }^{125} \mathrm{I}-\mathrm{bFGF}$ as described above. Retinas from injected eyes were removed and incubated for $2 \mathrm{hr}$ at $37^{\circ} \mathrm{C}$ in a humidified, $5 \% \mathrm{CO}_{2}$ atmosphere in Dulbecco's Modified Eagles Medium (Mediatech, Washington, DC) supplemented with $10 \%$ fetal calf serum, L-glutamine, and $50 \mathrm{~mm}$ HEPES, pH 7.4. The medium also contained $200 \mu \mathrm{M}$ unlabeled bFGF to block further uptake of ${ }^{125}$ I-bFGF and to dissociate ${ }^{125}$ I-bFGF bound to surface receptors prior to processing for SDS-PAGE. Tissues were dissolved in SDS treatment buffer, heated in boiling water for 5 min, sonicated, and then centrifuged at $8000 \times g$ to remove insoluble material. The supernatants (about $100 \mu \mathrm{l}$ ) were electrophoresed on 4 $20 \%$ gradicnt SDS polyacrylamide gels at constant voltagc. The gcls were stained with Coomassie blue and dried. Autoradiograms were made with Kodak X-Omat AR film with a Dupont Cronex lightningplus intensifying screen at $-70^{\circ} \mathrm{C}$.

Rate of loss of ${ }^{125} I-b F G F$ from the superior colliculus. Rats were injected in the posterior chamber of the eye with ${ }^{125}$ I-bFGF; $24 \mathrm{hr}$ later, the same eye was injected with 250 -fold excess of unlabeled bFGF to block further uptake and transport of radioactivity. The animals were then killed at various times, the superior colliculi dissected, and radioactivity determined.

\section{Results}

Crosslinking of ${ }^{225} \mathrm{I}-\mathrm{bFGF}$ to its receptor

The bFGF analog used in this study, though shown to be biologically active (Fox et al., 1988), had not been directly demonstrated to bind to FGF receptors. To demonstrate that the iodinated derivative of this bFGF retained receptor-binding ability, a crosslinked receptor assay was performed with BHK21 cells, a cell line that is a rich source of bFGF receptors (Neufeld and Gospodarowicz, 1986). The intensity of the signal (Fig. 1, lane A-) from the crosslinked, ${ }^{125} \mathrm{I}-\mathrm{bFGF-receptor} \mathrm{com-}$ plex at the molecular weight of about $160,000 \mathrm{Da}$ was very low, making resolution of the complex difficult. This is not surprising since most studies that clearly demonstrate receptor-ligand complexes in a crosslinking paradigm utilize antibodies to the receptor to immunoprecipitate and concentrate the complex prior to separation by SDS-PAGE. Because there are no antibodies to the bFGF receptor, we used a wheat germ agglutininaffinity gel to concentrate the glycosylated bFGF receptor and thus enhance the signal. Wheat germ agglutinin binds to, and has previously been used in the isolation of, the FGF receptor (Imamura et al., 1988; Lee et al., 1990). Figure 1, lane B-, shows the enhanced signal obtained after wheat germ lectinSepharose 6BM was used; the major ${ }^{125}$ I-bFGF-receptor complex has a molecular weight of approximately 160,000 Da. After subtracting the molecular weight of bFGF (17,800 Da), the primary FGF receptor remains with a molecular weight of about $142,200 \mathrm{Da}$, which is in good agreement with the value reported by Neufeld and Gospodarowicz (1986). Because the binding of ${ }^{125} \mathrm{I}-\mathrm{bFGF}$ to this receptor was blocked by addition of excess unlabeled bFGF (Fig. 1, lane $\mathrm{B}+$ ), it can be concluded that the iodinated derivative of the bFGF analog used in this study binds specifically to the FGF receptor and that wheat germ agglutinin binds to the receptor.

\section{$b F G F$ is not retrogradely transported in peripheral sympathetic, sensory, or motor axons}

To determine whether bFGF can be specifically retrogradely transported in peripheral sympathetic, sensory, or motor nerves,
${ }^{125}$ I-bFGF was injected into tissues innervated by these nerves. ${ }^{125} \mathrm{I}-\mathrm{NGF}$ was used as a positive control because it is retrogradely transported in peripheral sensory and sympathetic axons (for review, see Schwab and Thoenen, 1983). ${ }^{125}$ I-cytochrome c, a molecule of similar size and isoelectric point to NGF and bFGF was used as one negative control. ${ }^{125} \mathrm{I}-\mathrm{XFGF}$, a biologically inactive, acid-denatured form of bFGF, was used as another negative control. Identical amounts of the radiolabeled ligands were injected into the lower leg muscles and foot pads of adult rats whose sciatic nerves had been ligated at midthigh. After allowing sufficient time $(18 \mathrm{hr}$ ) for the uptake and retrograde transport of the ligands, $3 \mathrm{~mm}$ lengths of sciatic nerve immediately proximal and distal to the ligation were removed, and the amount of radioactivity in those tissues was measured. Figure $2 A$ shows that ${ }^{125} \mathrm{I}-\mathrm{NGF}$ accumulated distal to the ligation on the sciatic nerve, indicating uptake and retrograde transport in this nerve. In contrast to ${ }^{125} \mathrm{I}-\mathrm{NGF}$, only relatively low levels of ${ }^{125} \mathrm{I}-\mathrm{bFGF}$ accumulated distal to the ligation, and these levels of radioactivity were identical to those which resulted from nonspecific uptake and transport of ${ }^{125} \mathrm{I}$-cytochrome $c$ or ${ }^{125} \mathrm{I}-\mathrm{XFGF}$. Since the sciatic nerve is composed of motor, sensory, and sympathetic axons, these results indicate that bFGF was not specifically retrogradely transported in detectable quantities in these axons in the adult rat. While the adult motor neurons of the rat sciatic nerve do not take up and retrogradely transport ${ }^{125} \mathrm{I}-\mathrm{NGF}$, those of the newborn rat do (Yan et al., 1988). Therefore, to test the possibility that axons within the newborn rat sciatic nerve may transport ${ }^{25} \mathrm{I}-\mathrm{bFGF}$, the ligated sciatic experiments were repeated in newborn rats. Again, no significant accumulation of ${ }^{125} \mathrm{I}$-bFGF distal to the ligation was observed (results not shown). In another attempt to demonstrate uptake and retrograde transport of ${ }^{125} \mathrm{I}-\mathrm{bFGF}$ in peripheral axons, radiolabeled ligands were injected into the anterior chamber of the eye. Both sympathetic and sensory nerves innervate the iris; the retrograde transport of ${ }^{125}$ I-NGF from this tissue has been well studied (Schwab and Thoenen, 1983). ${ }^{125}$ I-NGF was found to accumulate specifically within the ipsilateral superior cervical ganglion (Fig. 2B). This ganglion, which supplies sympathetic innervation for the injected eye, however, did not show any specific accumulation of ${ }^{125} \mathrm{I}-\mathrm{bFGF}$; the amount of radioactivity accumulated was identical to that of the negative controls. Likewise, Figure $2 C$ shows that, in contrast to ${ }^{125} \mathrm{I}-\mathrm{NGF}$, which is retrogradely transported from the iris through sensory neuronal axons to the trigeminal ganglion, ${ }^{125}$ I-bFGF was not specifically taken up and transported in these sensory nerves of the adult rat. Thus, these data are consistent with the absence of receptormediated retrograde transport of bFGF in the peripheral sensory, sympathetic, or motor axons.

\section{$b F G F$ is anterogradely transported within the visual system}

In the intraocular (anterior chamber) injection experiments, we were surprised to detect ${ }^{125} \mathrm{I}-\mathrm{bFGF}$ radioactivity in the optic nerve of the injected eye (data not shown). To determine whether this uptake and transport was specific, ${ }^{125} \mathrm{I}-\mathrm{bFGF},{ }^{125} \mathrm{I}-\mathrm{bFGF}$ in the presence of excess unlabeled bFGF, ${ }^{125} \mathrm{I}-\mathrm{XFGF}$, or ${ }^{125} \mathrm{I}-\mathrm{NGF}$ was injected into the posterior chamber of the eye. The rats were allowed to survive for $18 \mathrm{hr}$ before tissues containing retinal ganglion cell projections were removed to determine the amount of radioactivity present. Retinal ganglion cells send axons through the optic nerve, the vast majority of which cross in the optic chiasm and project to the contralateral lateral geniculate body and then onto the contralateral superior colliculus 


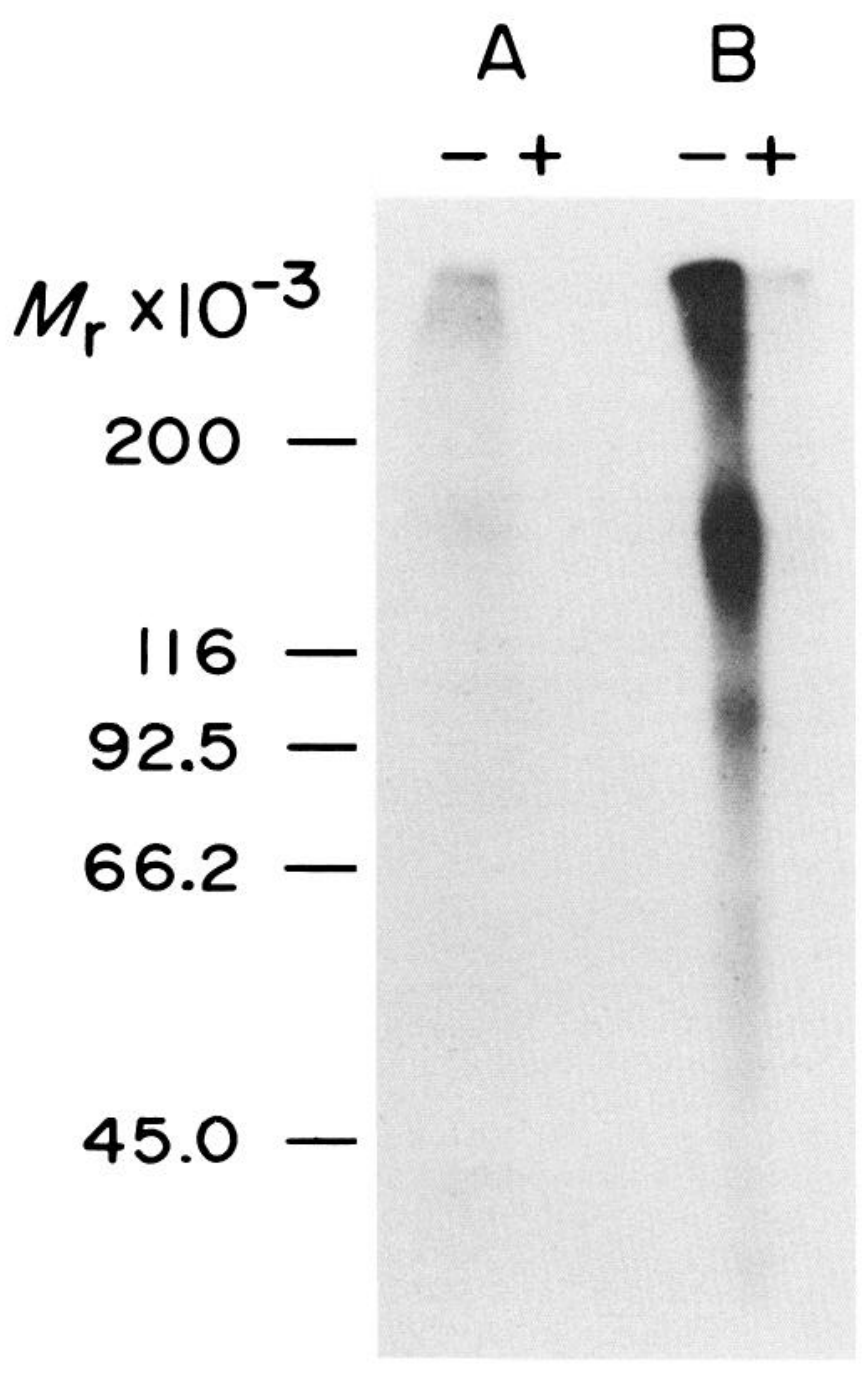

Figure 1. ${ }^{125}$ I-bFGF binds to high-affinity receptors on BHK-21 cells. ${ }_{125}$ I-bFGF was crosslinked to identical numbers of BHK-21 cells in the absence $(-)$ or presence $(+)$ of excess unlabeled bFGF. Cells were solubilized and the supernatant $(A)$ or the supernatant protein $(B)$ that bound to wheat germ lectin-Sepharose $6 \mathrm{MB}$ was separated by SDSPAGE using 7\% acrylamide gels. Gels were dried and exposed to X-ray film for $3 \mathrm{~d}$. The use of immobilized wheat germ lectin $(B)$ enhanced the detection of ${ }^{125}$ I-FGF-receptor complex.

(Sefton and Dreher, 1985). Although substantial amounts of radioactivity remain in the injected eye (Fig. $3 A$ ) after $18 \mathrm{hr}$, significant amounts of radioactivity from ${ }^{125} \mathrm{I}-\mathrm{bFGF}$ can also be found in the optic nerve of the injected eye (Fig. $3 B$ ), the contralateral lateral geniculate body (Fig. 3C), and the contralateral superior colliculus (Fig. 3D). Very little radioactivity was detected in the contralateral optic nerve, the ipsilateral lateral geniculate body, or the ipsilateral superior colliculus. These findings suggest retinal ganglion cell uptake and anterograde transport of bFGF. The ${ }^{125}$ I-bFGF-derived radioactivity transported to the superior colliculus was on the order of $0.1 \%$ of the total injected radioactivity. This percentage uptake is similar to the accumulation obtained in the superior cervical ganglion when sympathetic axons retrogradely transport ${ }^{125} \mathrm{I}-\mathrm{NGF}$ after injection in the anterior chamber of the eye (Fig. $3 B$; Johnson et al., 1978). To determine whether this uptake and anterograde trans-

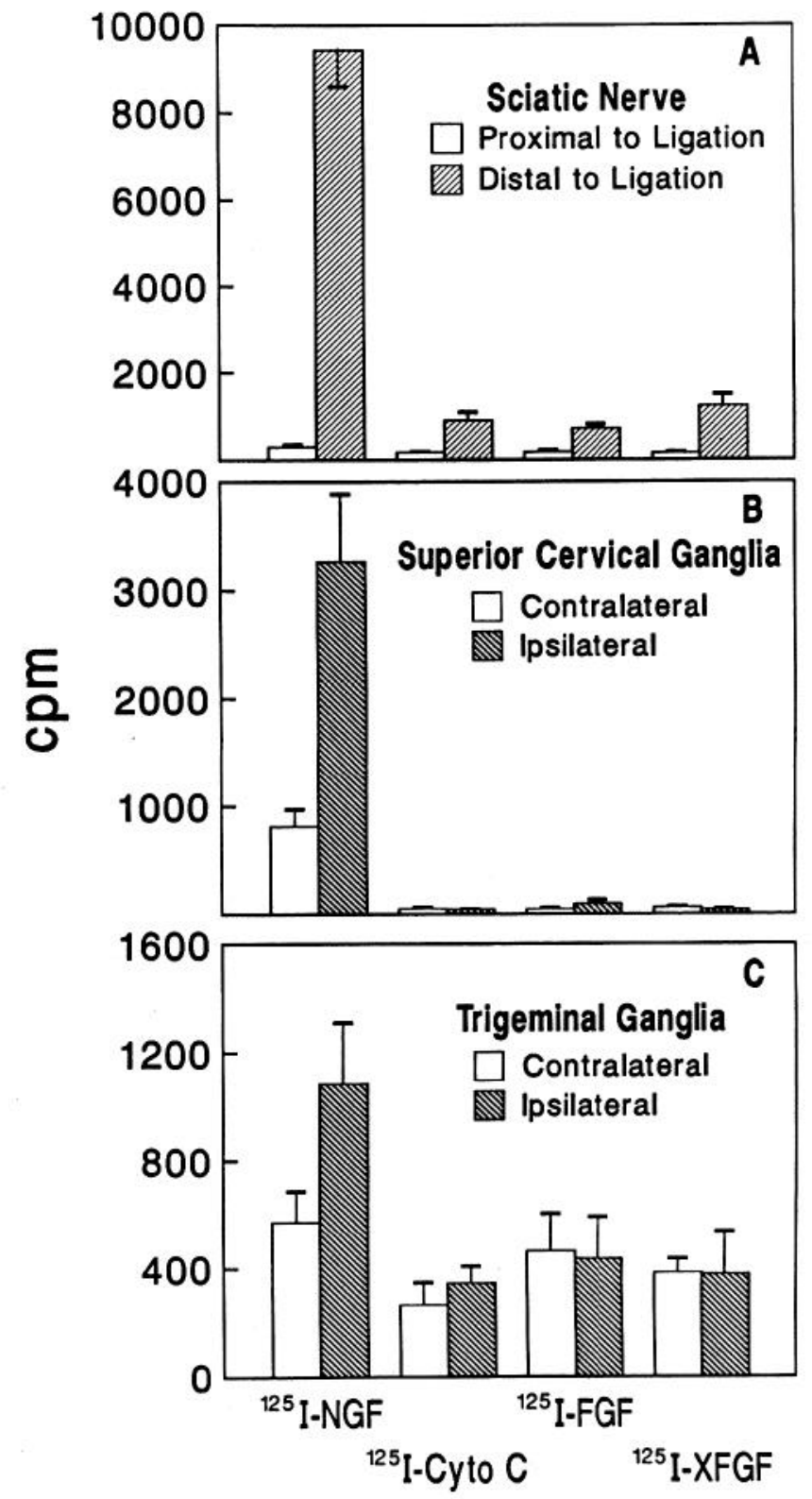

Figure 2. ${ }^{125} \mathrm{I}-\mathrm{bFGF}$ is not retrogradely transported in peripheral motor, sympathetic, or sensory axons. Accumulation of radioactivity 18 $\mathrm{hr}$ after injections proximal or distal to a ligation in the sciatic nerve $(A)$, in the ipsilateral and contralateral superior cervical ganglia $(B)$, and in the ipsi- and contralateral trigeminal ganglia $(C)$. Similar amounts of radiolabeled ligands were injected into the lower leg muscles and foot pad or into the anterior chamber of the eye. Means \pm SEM $(n=6)$. Only ${ }^{125}$ I-NGF shows a statistically significant accumulation of radioactivity compared to the negative control ${ }^{125} \mathrm{I}$-cytochrome $\mathrm{c}$.

port of ${ }^{125} \mathrm{I}-\mathrm{bFGF}$ is a saturable phenomenon, a 275 -fold excess of unlabeled bFGF was injected with the ${ }^{125} \mathrm{I}-\mathrm{bFGF}$. The unlabeled bFGF (Fig. 3, +Cold) blocked the transport of radioactivity from injected ${ }^{125} \mathrm{I}$-bFGF within the retinal projections. This indicates that receptors probably mediate the uptake and transport of bFGF by retinal ganglion cells. To examine further the specificity of the uptake and transport of ${ }^{125} \mathrm{I}-\mathrm{bFGF},{ }^{125} \mathrm{I}-$ XFGF (denatured bFGF) was injected intraocularly. It was not transported within the optic system, indicating that the tertiary structure of the bFGF molecule is important if bFGF is to be internalized and transported. To determine whether retinal gan- 


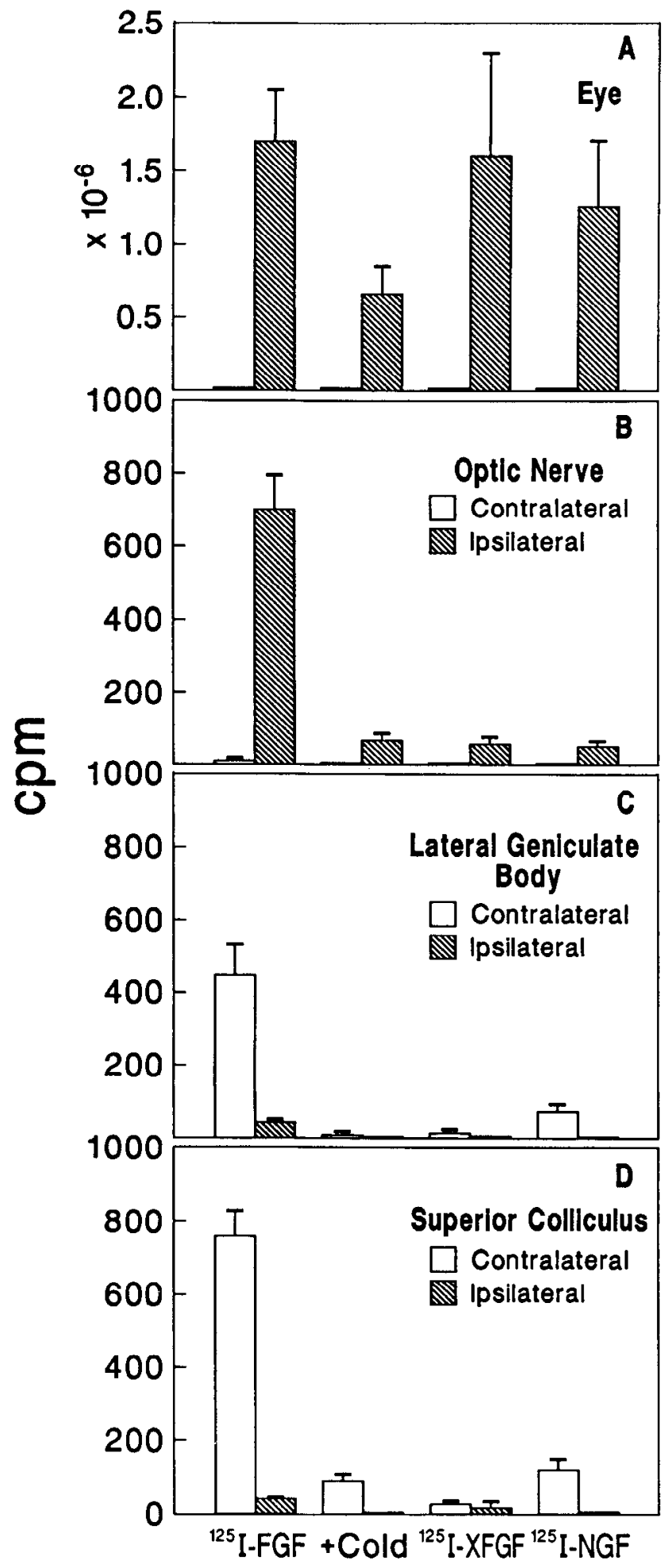

Figure 3. Specificity of transport of ${ }^{125} \mathrm{I}$-bFGF in the visual system. Accumulation of ${ }^{225}$ I-labeled ligands in the ipsilateral (injected) and contralateral eye $(A)$, optic nerve $(B)$, lateral geniculate body $(C)$, and superior colliculus $(D), 18 \mathrm{hr}$ after intraocular injection. Similar amounts of radiolabeled ligand were injected. Means \pm SEM $(n=6)$. Only ${ }^{125} \mathrm{I}-$ bFGF demonstrates significant transport and a 275 -fold excess of unlabeled bFGF blocks uptake and transport of this ligand. glion cells have a general capacity to internalize and transport growth factors in an anterograde direction, ${ }^{125}$ I-NGF was injected. The amount of radioactivity detected in the superior colliculus after ${ }^{125}$ I-NGF injection was not significantly different ( $p>0.1$; Student's 2-tailed $t$-test) from the amount of radioactivity detected after injections of either ${ }^{125} \mathrm{I}-\mathrm{X} \mathrm{FGF}$ or ${ }^{125} \mathrm{I}-$ bFGF injected with an excess unlabeled bFGF. These data indicate that the uptake and transport of bFGF is spccific and probably receptor mediated.

\section{Modulators of bFGF binding affect axonal transport}

High-affinity receptors and lower-affinity, heparin-binding sites for bFGF have been demonstrated (Moscatelli, 1987). To determine which binding site mediates the internalization and axonal transport of bFGF in retinal ganglion cells, substances previously reported to interfere in vitro with the binding of bFGF either to its receptor or to heparin-like substances were injected concomitantly with ${ }^{125}$ I-bFGF (Fig. 4). Although interpretation of the data is complicated by the in vivo nature of these studies (where modulators can have effects other than solely interfering with bFGF binding), the observation that radioactivity transported to the superior colliculus was decreased in the presence of a modulator would be consistent with the blockade of bFGF binding and/or internalization; similarly, a reduction in the amount of label retained within the eye $18 \mathrm{hr}$ after injection would be consistent with a reduced retention of bFGF within the eye. Wheat germ agglutinin blocks binding of bFGF to its high-affinity receptor (Feige and Baird, 1988). Intraocular injection of wheat germ agglutinin blocked uptake and transport of ${ }^{125} \mathrm{I}-\mathrm{bFGF}$ to the superior colliculus (Fig. $4 B$ ), suggesting that it is the high-affinity bFGF receptors that mediate axonal transport of ocular bFGF. Basic FGF binds strongly to heparin (Gospodarowicz et al., 1987) and heparin-like molecules mediate the binding of bFGF to cells (Moscatelli, 1987) and extracellular matrix (Bashkin et al., 1989). Heparinase treatment destroys this binding (Moscatelli, 1987) and biologically active bFGF is released (Bashkin et al., 1989). Heparinase treatment does not destroy the high-affinity bFGF receptor (Moscatelli, 1987). When heparinase was injected with ${ }^{125}$ I-bFGF into the eye, the amount of radioactivity transported to the superior colliculus was not reduced (Fig. $4 B$ ). This is consistent with the internalization of bFGF being mediated not by heparin-like binding sites but rather by the high-affinity receptor. The basement membrane of the eye has substantial binding capacity specific for the bFGF and aFGF (Jeanny et al., 1987). Heparin-like substances account for the bulk of the ${ }^{125} \mathrm{I}-\mathrm{bFGF}$ binding to the substrate in tissue culture preparations of bovine capilliary endothelial cells; less than $10 \%$ of added ${ }^{125}$ I-bFGF binds directly to high-affinity receptors (Moscatelli, 1988). The initial binding of bFGF to heparin-like binding sites is thought to serve as a source of bFGF that eventually binds to high-affinity sites and is internalized by the cell (Moscatelli, 1988). Heparin competitively inhibits the initial binding of bFGF to heparin-like substances (Moscatelli, 1988). When heparin was co-injected with ${ }^{125} \mathrm{I}-\mathrm{bFGF}$, relatively little of the radioactivity was retained within the eye $18 \mathrm{hr}$ after injection (Fig. $4 A$ ). Thus, the rapid clearance of ${ }^{125} \mathrm{I}$ bFGF in the presence of either heparin or heparinase (Fig. 4A) indicates that heparin-like substances within the eye are responsible for the long-term retention of bFGF within the eye; bFGF not bound to insoluble heparin-like substances is rapidly cleared from the eye by an unknown mechanism. Unlike heparin- 
ase, which did not block the anterograde transport of ${ }^{125}$ I-bFGFderived radioactivity, relatively little radioactivity was anterogradely transported in the presence of heparin (Fig. $4 B$ ). This difference probably reflects the different mechanisms of action of heparinase and heparin, coupled with the rapid clearance of ${ }^{125}$ I-bFGF not bound to heparin-like substances within the eye. In the presence of heparin, much of the ${ }^{125} \mathrm{I}-\mathrm{bFGF}$ remains in solution. Because the binding of ${ }^{125} \mathrm{I}-\mathrm{bFGF}$ to receptors on retinal ganglion cells is saturable (Fig. 3), only a limited amount of the ${ }^{125}$ I-bFGF binds, and is anterogradely transported, before the bulk of the soluble ${ }^{125} \mathrm{I}-\mathrm{bFGF}$ is cleared from the eye when heparin is present. Heparinase, however, should not inhibit the initial binding of ${ }^{125} \mathrm{I}$-bFGF to heparin-like substances; rather it enzymatically destroys these binding sites. Much of the ${ }^{125} \mathrm{I}-$ bFGF co-injected with heparinase is likely to bind first to heparin-like substances within the eye and thus be prevented from being rapidly cleared from the eye. Subsequently, however, heparinase will accelerate the liberation of ${ }^{125} \mathrm{I}-\mathrm{bFGF}$ from heparin-like binding sites and provide a local elevated level of soluble ${ }^{125}$ I-bFGF available for receptor-mediated uptake and anterograde transport. Such a phenomenon may account for the increased amounts of ${ }^{125} \mathrm{I}-\mathrm{bFGF}$-derived radioactivity recovered from the superior colliculus of heparinase-treated animals (Fig. 4). While this is speculation, it is clear that heparinlike substances are present within the eye and that bFGF can bind to them. However, it is not these heparin-like substances, but rather high-affinity bFGF receptors, that mediate the internalization and anterograde transport of ocular bFGF within the retinal ganglion cell.

\section{$b F G F$ is not retrogradely transported in retinal ganglion axons}

The demonstration that retinal ganglion cell neurons express bFGF receptors and transport radioactivity from ${ }^{125} \mathrm{I}-\mathrm{bFGF}$ in an anterograde direction led us to determine whether bFGF can be transported in a receptor-mediated manner in a retrograde direction from the superior colliculus to the retina. ${ }^{125} \mathrm{I}-\mathrm{bFGF}$ was injected into the superior colliculus and the amount of radioactivity in the retinas was determined $24 \mathrm{hr}$ later. Considering the amount of ${ }^{125} \mathrm{I}-\mathrm{bFGF}\left(10^{6} \mathrm{cpm}\right)$ injected into the superior colliculus, only very low levels of radioactivity were retrogradely transported to the contralateral eye (Table 1). This retrograde transport, however, was probably not receptor mediated: the difference between the amount of radioactivity transported from the superior colliculi in the absence, and that transported in the presence, of an excess of unlabeled bFGF was not statistically significant. A statistically significant difference between these 2 data points would have been consistent with a saturable, receptor-mediated uptake phenomenon. The failure to demonstrate receptor-mediated retrograde transport of ${ }^{125} \mathrm{I}$ bFGF was not because of faulty injection technique; about $20 \%$ of the radioactivity remained within the superior colliculus 24 $\mathrm{hr}$ after injection, and identical injections of HRP into the optic layer of the superior colliculus (Fig. 5A) resulted in the retrograde labeling of retinal ganglion cell bodies in the contralateral retina (Fig. $5 B$ ), as has previously been demonstrated (Linden and Perry, 1983). The failure to demonstrate specific receptor-mediated retrograde transport of bFGF might indicate the absence of receptors on surfaces of the retinal ganglion cell terminals in the superior colliculus or the lack of a mechanism for retrogradely transporting bFGF in these axons. Similar negative results were obtained after ${ }^{175} \mathrm{I}-\mathrm{bFGF}$ was injected into the lateral geniculate body (results not shown).

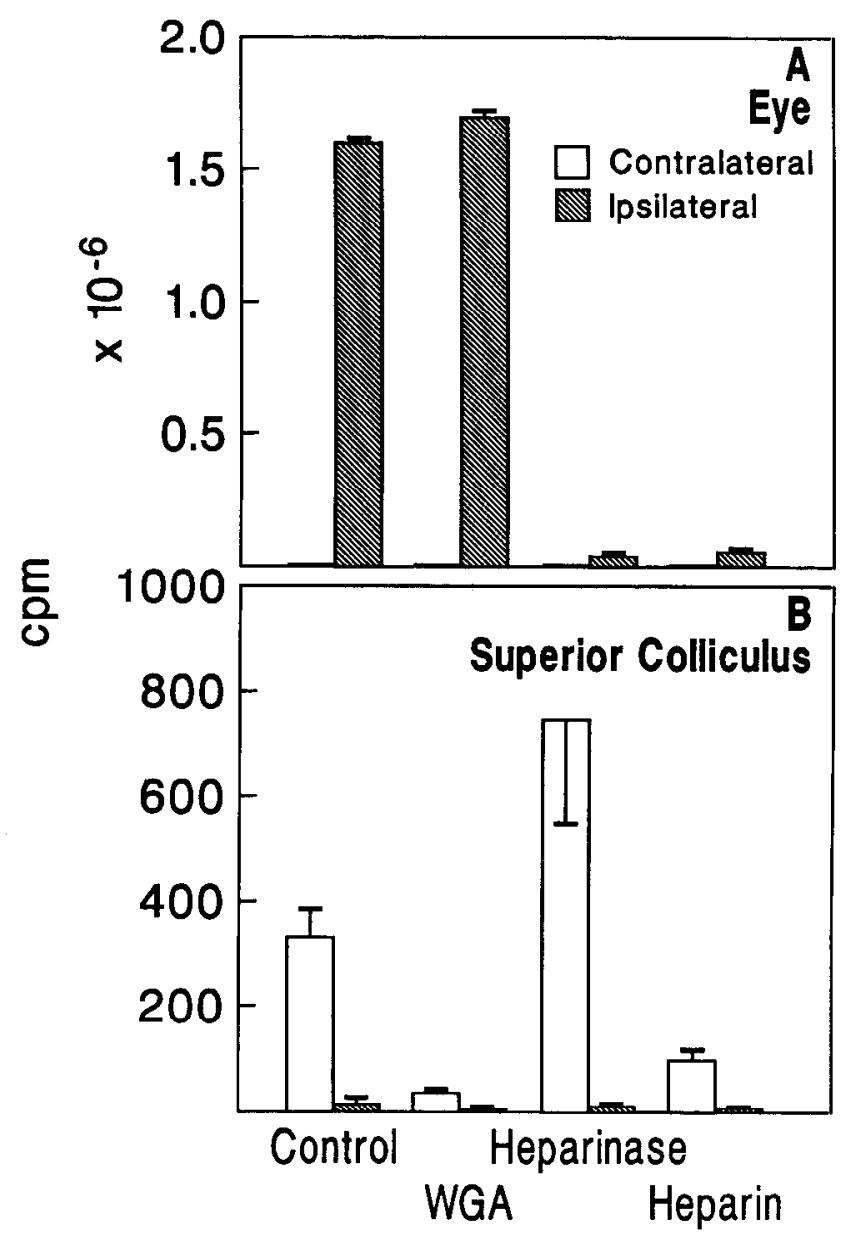

Figure 4. Effects of modulators of bFGF binding on uptake and transport. The amount of radioactivity remaining in the eye $(A)$ or in the superior colliculi $(B) 18 \mathrm{hr}$ after intraocular injection of ${ }^{125} \mathrm{I}-\mathrm{bFGF}$ (control) or ${ }^{125} \mathrm{I}-\mathrm{bFGF}$ in the presence of wheat germ agglutinin (WGA), heparinase, or heparin. Means $\pm \operatorname{SEM}(n=6)$.

\section{Autoradiography of anterogradely transported radioactivity}

Autoradiographic localization was performed to allow a more precise anatomical localization of radioactivity after intraocular injection of ${ }^{125} \mathrm{I}-\mathrm{bFGF}$. In serial coronal sections, concentrations of silver grains were, on the whole, confined to known projections of the rctinal ganglion cell (Sefton and Dreher, 1985). Prominent labeling was observed over the superior colliculus (Fig. 6, $A, B$ ) and lateral geniculate body (Fig. 6C). Substantially more radioactivity was present in the superior colliculus after intraocular injection of ${ }^{125} \mathrm{I}$-bFGF (Fig. $6 B$ ) than after intraocular injection of ${ }^{125} \mathrm{I}$-XFGF (Fig. $6 \mathrm{D}$ ). The accumulation of some radioactivity after ${ }^{125} \mathrm{I}-\mathrm{XFGF}$ injection was not unexpected because $17.5 \pm 0.2 \%(n=3)$ of the ${ }^{125} \mathrm{I}$-XFGF preparation retained a strong affinity for heparin (by heparin column chromatography), indicating presence of native ${ }^{125} \mathrm{I}-\mathrm{bFGF}$. Thus, this proportion of the ${ }^{125} \mathrm{I}-\mathrm{XFGF}$ preparation might be expected to undergo receptor-mediated axonal transport. Other optic structures that showed prominent labeling included the optic chiasm, the suprachiasmatic nucleus, the pretectal nucleus, and the medial terminal accessory nucleus of the optic tract (Fig. 7). While the dense labeling was confined to the side contralateral to the injected eye, very slight labeling of optic structures on the ipsilateral side could be appreciated on some sections (results not 


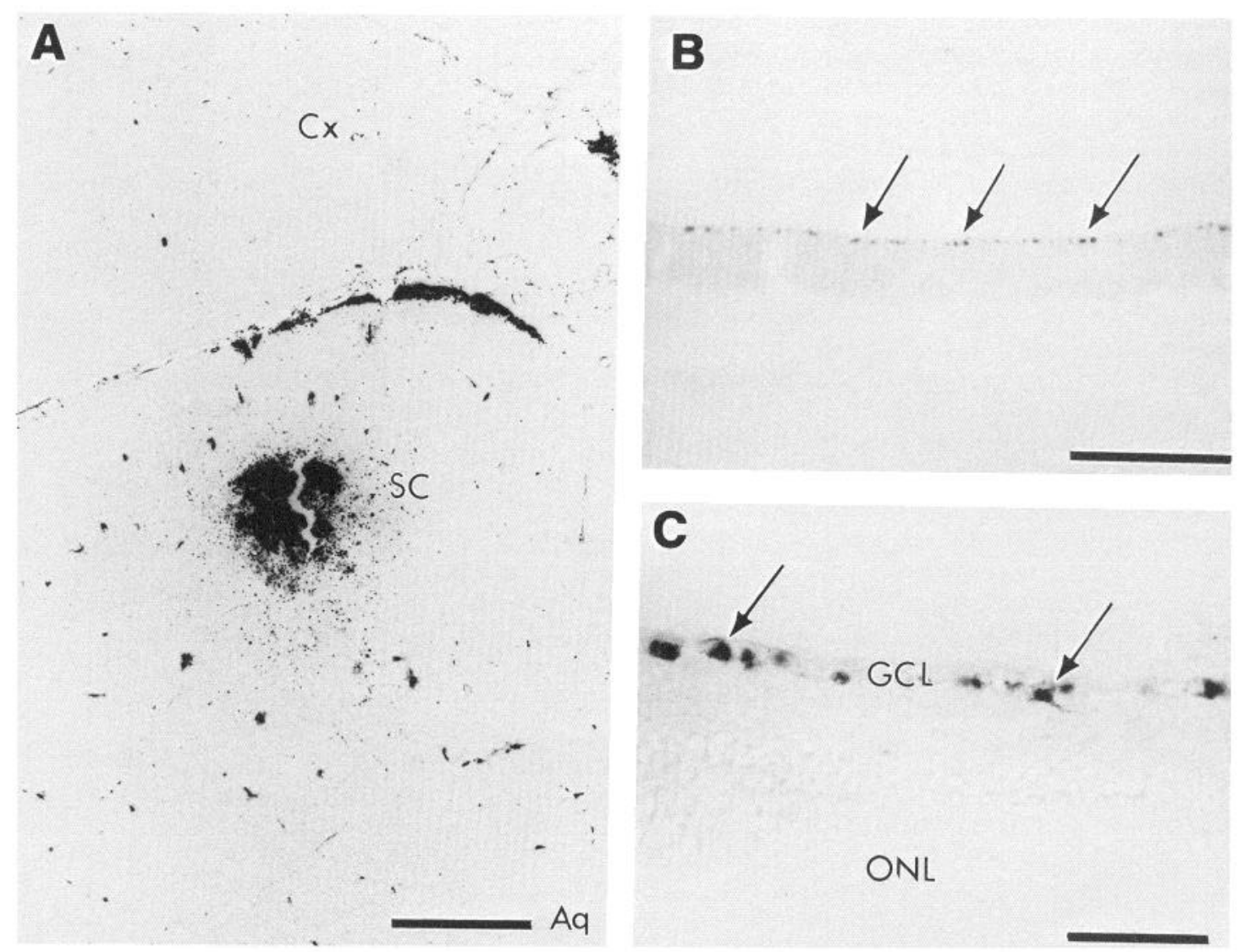

Figure 5. HRP in the superior colliculus and the retinal ganglion cells $24 \mathrm{hr}$ after injection into the superior colliculus. $A$, HRP reaction product at injection site in the superior colliculus. $C x$, cerebral cortex; $S C$, superior colliculus; $A q$, cerebral aquiduct. $B$, HRP reaction product (arrows) in the retinal ganglion cell layer of the contralateral retina. $C$, Higher-magnification view of $B$. HRP reaction product within retinal ganglion cells (arrows). GLC, ganglion cell layer; $O N L$, outer nuclear layer. Scale bars in $A, 500 \mu \mathrm{m} ; B, 200 \mu \mathrm{m} ; C, 50 \mu \mathrm{m}$.

shown). The presence of low densities of silver grains over ipsilateral projections is consistent with reports that $<10 \%$ of the retinal ganglion cell axons project to the ipsilateral side (Sefton and Dreher, 1985).

We wondered whether the anterograde transport system demonstrated in these studies serves to transport endogenous bFGF synthesized within the eye to the superior colliculus and lateral geniculate body to provide trophic support for these neurons. This is of interest because it has long been known that an anterograde transneuronal degeneration follows optic nucleation or optic nerve sectioning (for review, see Cowan, 1970). ${ }^{125}$ IbFGF was injected intraocularly in the manner already described and the rats perfused transcardially with fixative 18 or $48 \mathrm{hr}$ later. Evaluation at $18 \mathrm{hr}$ would show the pattern of

Table 1. Amount of radioactivity (counts per min) in the ipsilateral and contralateral eye $24 \mathrm{hr}$ after injection into the superior colliculus of ${ }^{125}$ I-bFGF in the absence (bFGF) or presence (+ cold) of a 300-fold excess of unlabeled bFGF.

\begin{tabular}{lcl} 
Condition & Ipsilateral eye & Contralateral eye \\
\hline bFGF & $82.5 \pm 12.1$ & $154 \pm 46.8$ \\
bFGF + cold & $125 \pm 25.3$ & $176 \pm 32.6$
\end{tabular}

Data are means \pm SEM $(n=13)$. The difference between the contralateral bFGF and + cold data was not statistically significant $(p=0.7205$; Student's 2-tailed $t$ test). earliest-arriving ${ }^{125} \mathrm{I}-\mathrm{bFGF}$, while examination at $48 \mathrm{hr}$ would allow time for the possible accumulation of radiolabeled $\mathrm{bFGF}$ in postsynaptic elements of the brain tissue. Figures $6 A$ and $6 B$ compare the accumulation of radiolabel in the superior colliculus at 18 and $48 \mathrm{hr}$, respectively. Although higher densities of silver grains, indicating more radioactivity, were observed at 48 $\mathrm{hr}$ (Fig. 6B) than at $18 \mathrm{hr}$ (Fig. 6A) after intraocular injection, there was no observable difference in the distribution of silver grains. The lack of difference in the pattern of labeling at these 2 times suggests that if ${ }^{125}$ I-bFGF-derived radioactivity is being released from the retinal ganglion cell terminals, there may not be any accumulation of the radioactivity in the postsynaptic elements. While significant levels of radioactivity were not detected in visual cortex, above-background densities of silver grains were observed in the intermediate gray and the intermediate white layers of the superior colliculus (results not shown). These regions do not receive substantial retinal ganglion cell projections (Sefton and Dreher, 1985), thus raising the possibility that some radioactivity derived from ${ }^{125}$ I-bFGF may be released from the retinal ganglion cell terminals.

\section{Time course and rate of axonal transport of radioactivity in the visual system}

To determine the time course of uptake and transport of bFGF, the radioactivity within retinal ganglion cell projections was determined at a range of times in rats intraocularly injected with 

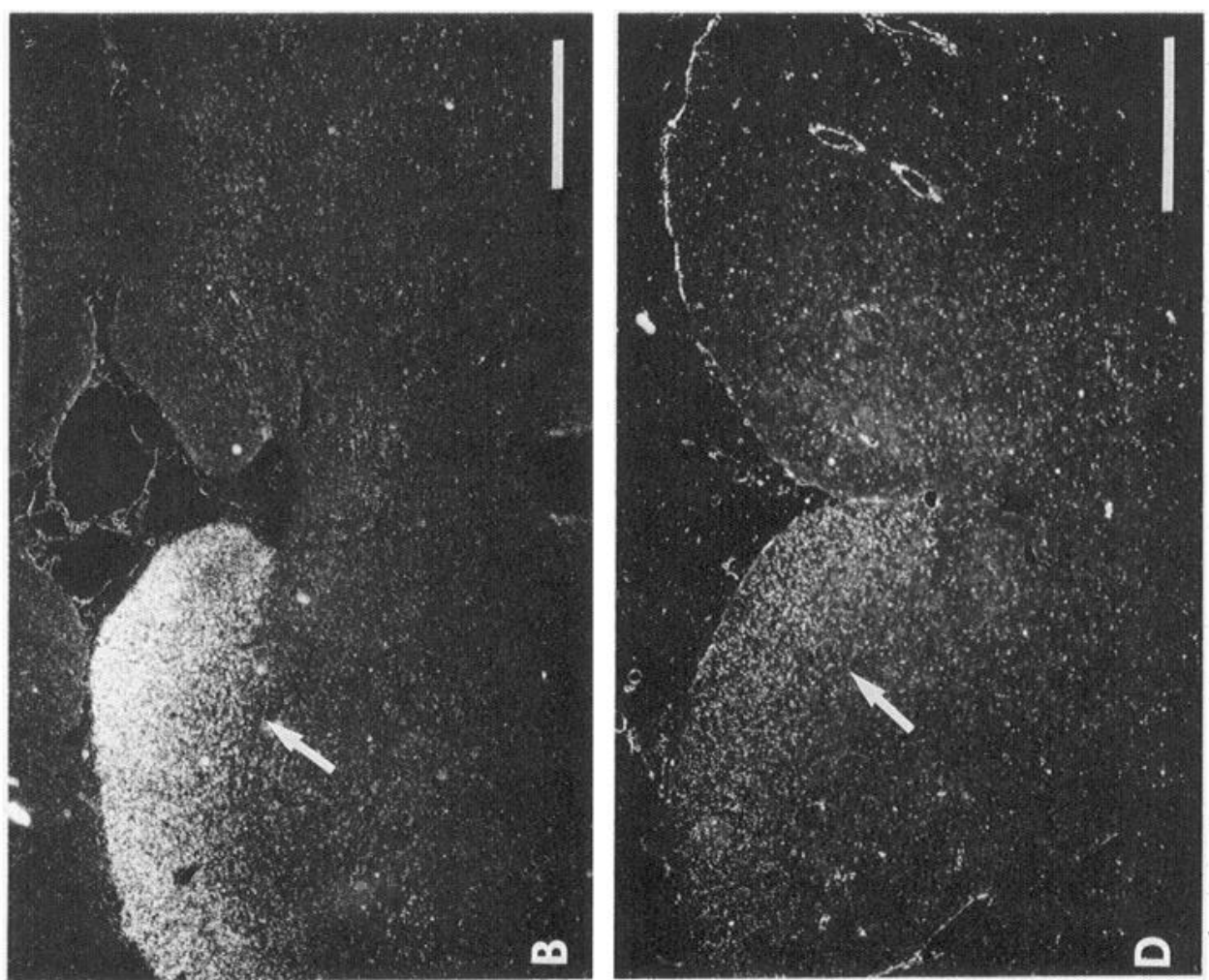

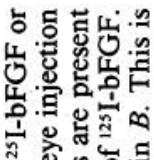
फ 里 ङ. ฐ

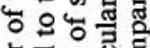

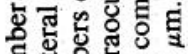
졍 콜영유

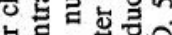
흥 엉웡 월록둰

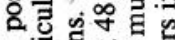

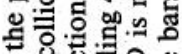
엉은 돋.․․․․ 응 氜了国 कै छี

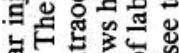
ㅂ. 잉

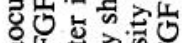

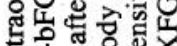

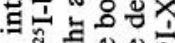
氙守焉它

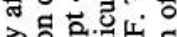
충요잉

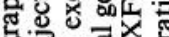
解牙它

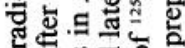

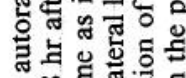

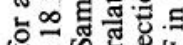

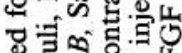
象

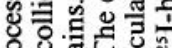

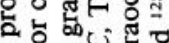
a. कोण

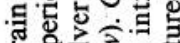

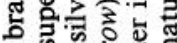

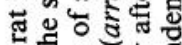

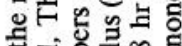

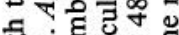

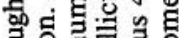
ํํ을 킁릉 氜矛过

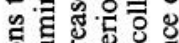
을을윽엉 远此

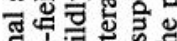

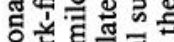

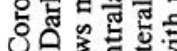
ชด 岂害

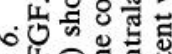

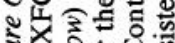

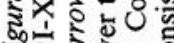



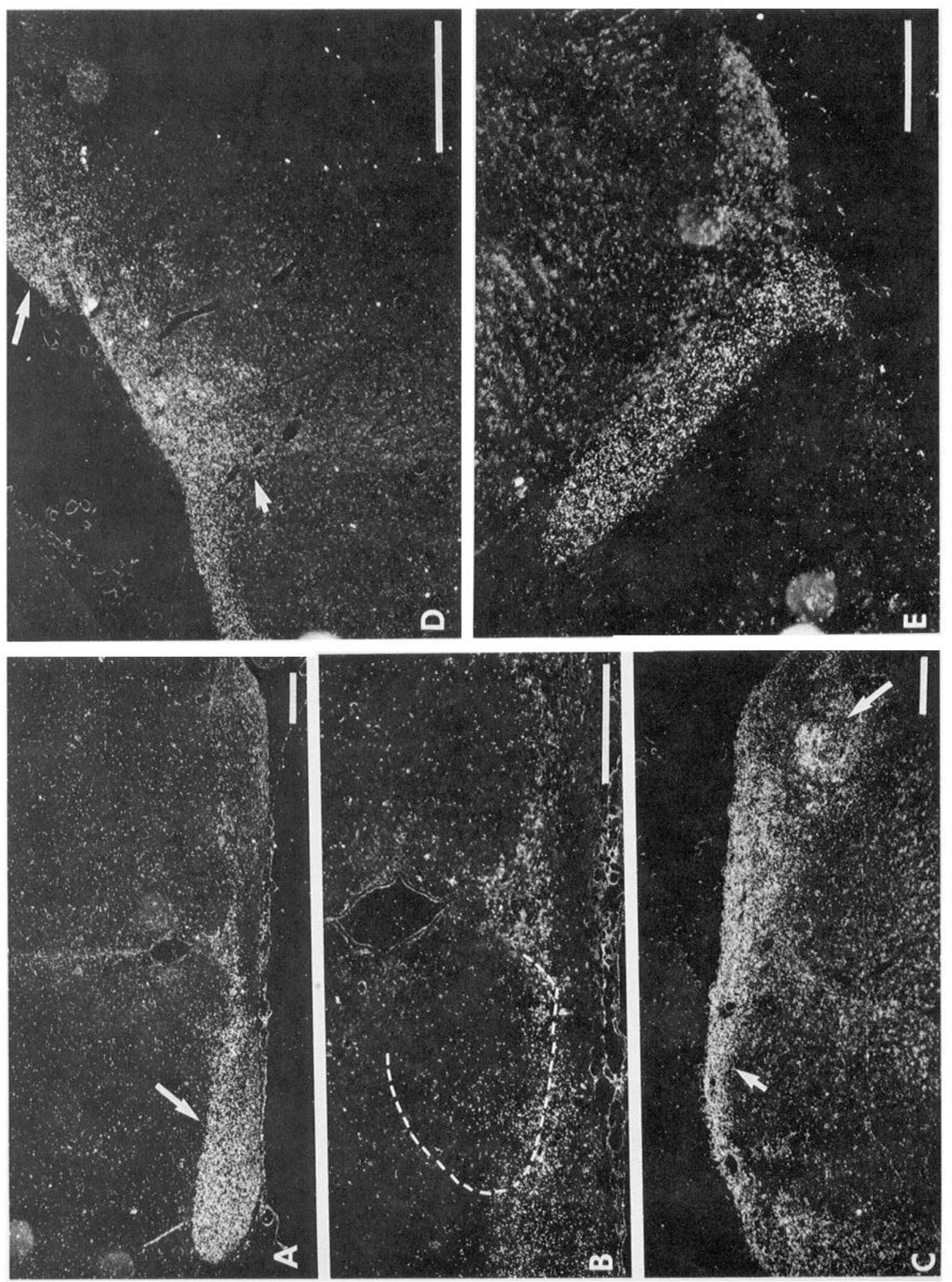

虫

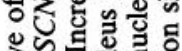
o. 7 .

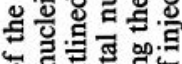

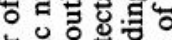
岁. ह . ज् 80

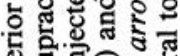
फ้ है.

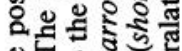
F 0 . . ㄷㅇㅇㅢ

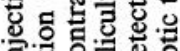

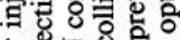

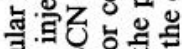
웡

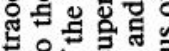

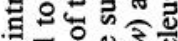
可狍言 क्ष प्र्मे के 与近응

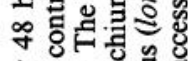
을 웜

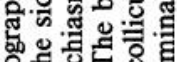

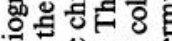

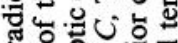
on

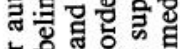
우응 论啳

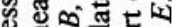
\&

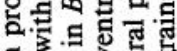
동

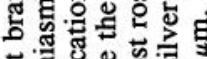

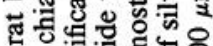

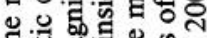
F क्ष हैं

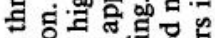

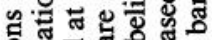
명 0 है हैं

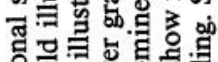

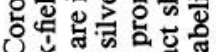
당 人

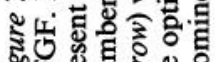

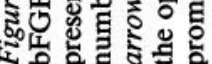


125 I-bFGF. A bimodal change in radioactivity levels with time was apparent (Fig. 8). An initial increase in the amount of radioactivity in both ipsi- and contralateral optic nerves, lateral geniculate bodies, and superior colliculi was observed soon after intraocular injection; by $9 \mathrm{hr}$ after injection the radioactivity in these tissues appeared to be returning toward background levels. A second increase in radioactivity was apparent from $9 \mathrm{hr}$ after injection; during this time, the amount of radioactivity in optic system tissues innervated by the injected eye began to increase, while the amount of radioactivity in the contralateral optic nerve and ipsilateral lateral geniculate body and superior colliculus continued to decrease toward background levels. The observed bimodal change in radioactivity levels in optic system tissues is the result of 2 independent processes. The first increase in the level of radioactivity of optic nerves, lateral geniculate bodies, and superior colliculi is the result of contamination of these tissues after leakage of radioactivity from the injection site. Evidence for this conclusion comes from (1) the similar levels of radioactivity detected in brain tissues irrespective of whether they are innervated by the injected eye; (2) the finding that only $40 \pm 18 \%(n=3)$ of the radioactivity in the $3 \mathrm{hr}$, contralateral superior colliculus was trichloroacetic acid (TCA) precipitable (note that the injection mixture consisted of both ${ }^{125} \mathrm{I}-\mathrm{bFGF}$ and unincorporated ${ }^{125} \mathrm{I}$ ); and (3) the rapid fall in radioactivity of the injected eye, indicating leakage of radioactivity. The second increase in radioactivity, observed after $9 \mathrm{hr}$, is the result of specific axonal transport of radioactivity. Evidence for this conclusion comes from (1) the significant levels of radioactivity only in brain tissue innervated by the injected eye and (2) the finding that $92 \pm 10 \%(n=3)$ of the radioactivity in the $15 \mathrm{hr}$ contralateral superior colliculus was TCA precipitable. During this second period of increasing radioactivity in optic system tissues, the amount of radioactivity remaining within the eye does not change substantially, suggesting that the eye may have significant capacity for binding bFGF. From this time course study we conclude that the appearance of radioactivity in optic system tissues from $9 \mathrm{hr}$ onward after the intraocular injection reflects specific axonal transport of ${ }^{125} \mathrm{I}-\mathrm{bFGF}$ and its derivatives.

Analysis of the time course of ${ }^{125}$ I-bFGF appearance in optic system tissues (Fig. 8) allowed the maximal rate of axonal transport of bFGF in retinal ganglion cell axons to be estimated. Initial attempts to ascertain the maximal rate of transport by determining the first appearance of radioactivity within optic nerves, lateral geniculate body, and superior colliculus were unsuccessful because, as noted earlier, there was widespread contamination of all ncural tissucs for the first $9 \mathrm{hr}$ after injection. However, by $18 \mathrm{hr}$, a statistically significant difference is observed between the amount of radioactivity present in the contralateral superior colliculus (innervated by the injected eye) compared to the noninnervated ipsilateral superior colliculus (Fig. 3). The earliest time at which such a statistically significant difference is observed is at $15 \mathrm{hr}$; there is no significant difference at $9 \mathrm{hr}$ (Fig. 8). Thus, ${ }^{125}$ I-bFGF-derived radioactivity first arrived in the superior colliculus some time before $15 \mathrm{hr}$. By using an estimated axonal distance from retina to superior colliculus of $25 \mathrm{~mm}$, the maximal rate of bFGF transport within the retinal ganglion cell axons can be estimated to be in excess of $1.7 \mathrm{~mm}$ / $\mathrm{hr}$. This rate of axonal transport is comparable to the maximal rate of retrograde transport of ${ }^{125} \mathrm{I}-\mathrm{NGF}$, which is about $3 \mathrm{~mm} /$ hr in sympathetic axons (Johnson et al., 1978).

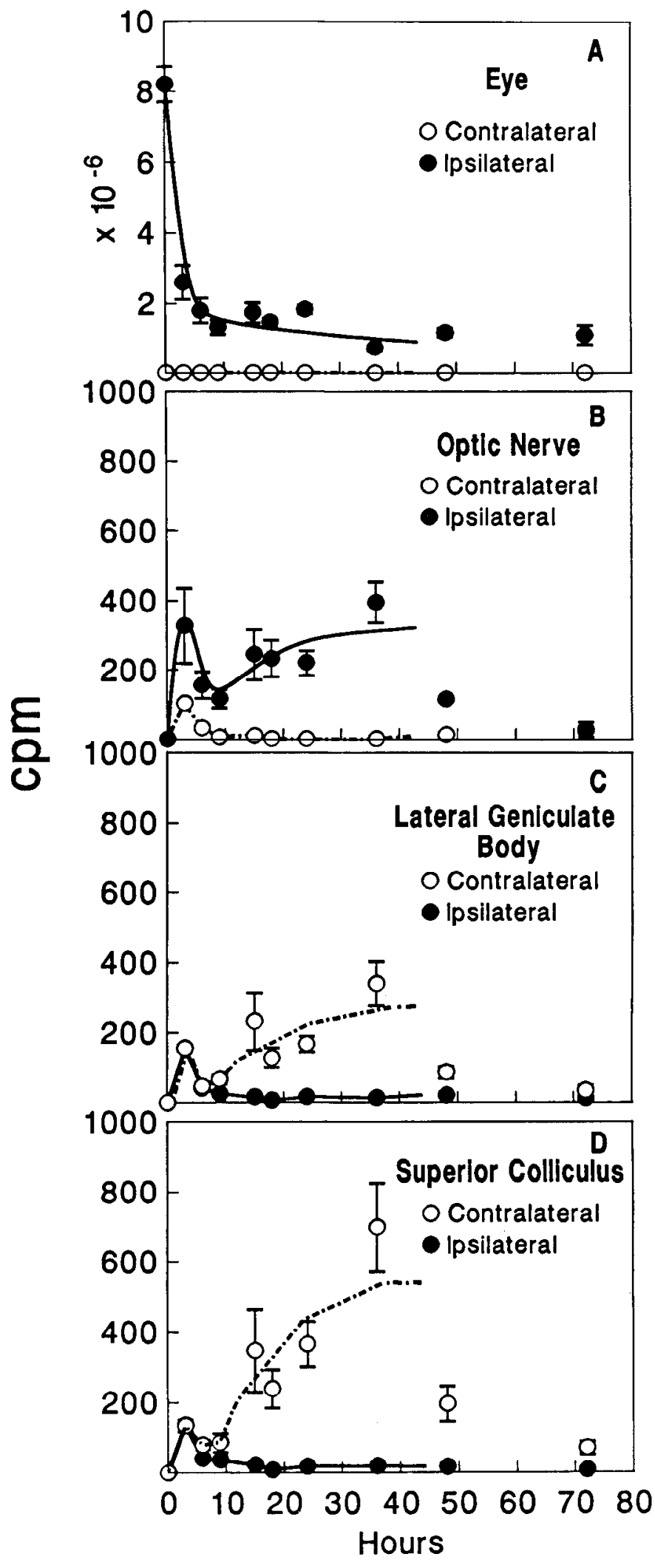

Figure 8. Time course of ${ }^{125} \mathrm{I}-\mathrm{bFGF}$ transport in the visual system. The accumulation of radioactivity in ipsilateral (filled symbols) and contralateral (open symbols) eye $(A)$, optic nerve $(B)$, lateral geniculate body $(C)$, and superior colliculus $(D)$ at various times after injection. Data are means \pm SEM ( $n=6$ for $3-36$ hr time points; $n=3$ for 48 and $72 \mathrm{hr}$ ). 


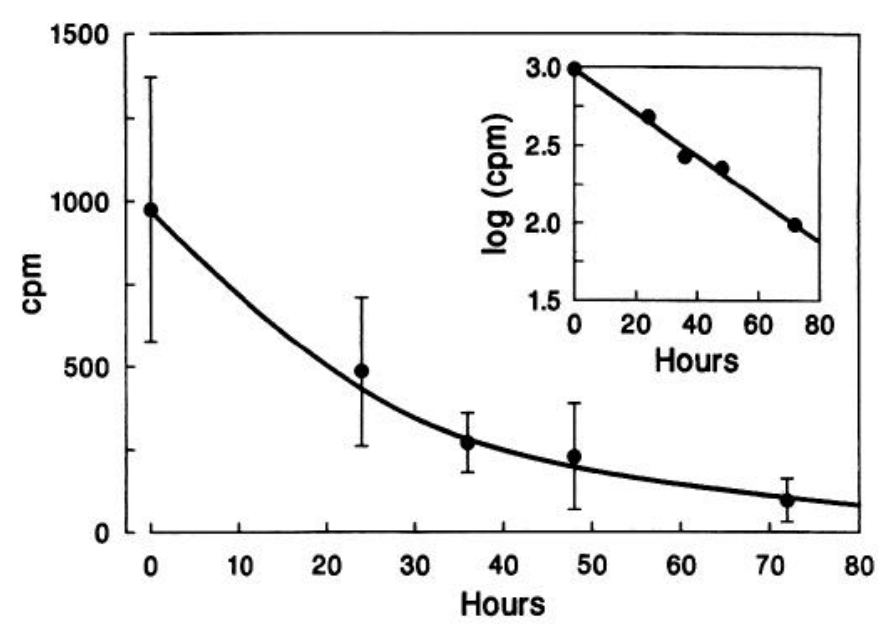

Figure 9. Time course of loss of ${ }^{125} \mathrm{I}-\mathrm{bFGF}$ from the superior colliculus. The amount of radioactivity in the superior colliculus is plotted against time. Means \pm SEM $(n=5)$. Inset, Logarithm of radioactivity (mean) plotted against time. A linear correlation was obtained $\left(r^{2}=0.991\right)$, and, from the slope of the line, a half-life of $22 \mathrm{hr}$ was calculated.

\section{Half-life of ${ }^{125} I-b F G F$ within the superior colliculus}

The foregoing evidence demonstrates that bFGF was rapidly transported in a unidirectional manner away from the retina. To determine how quickly the bFGF transported from the eye is lost from the superior colliculus, the tissues containing retinal ganglion projections were loaded with ${ }^{125} \mathrm{I}-\mathrm{bFGF}$ by intraocular injection followed $24 \mathrm{hr}$ later by an injection of excess, unlabeled bFGF to block further uptake of radioactivity. The superior colliculi were removed at various times and the radioactivity in those tissues was determined and plotted against time (Fig. 9). Slightly more than half the radioactivity was lost from the superior colliculus each $24 \mathrm{hr}$. A plot of the logarithm of the radioactivity against time (Fig. 9, insert) is linear (correlation coefficient, $r^{2}=0.991$ ), indicating a first-order rate of loss. From a regression analysis of the slope of the curve, the half-life of ${ }^{125} \mathrm{I}-\mathrm{bFGF}$ is calculated to be $22 \mathrm{hr}$.

\section{Ocular bFGF is proteolytically processed within retinal ganglion cells}

The loss of radioactivity from the superior colliculus could be the result of release of ${ }^{125} \mathrm{I}-\mathrm{bFGF}$ from retinal ganglion cell projections and/or its proteolytic degradation within those projections. To determine whether proteolytic degradation of internalized bFGF did occur, the radioactive proteins within optic tissues were separated by SDS-PAGE and then visualized by autoradiography. Results from 2 separate experiments are shown (Fig. 10). Although the quantities of protein species varied, the pattern was consistent: both intact ${ }^{125} \mathrm{I}-\mathrm{bFGF}$ and proteolytically clipped forms of ${ }^{125} \mathrm{I}-\mathrm{bFGF}$ can be found throughout the length of the retinal ganglion cell projections. Less of the intact ${ }^{125} \mathrm{I}-$ bFGF and more of the proteolytically clipped ${ }^{125} \mathrm{I}-\mathrm{bFGF}$ forms were found in $18 \mathrm{hr}$ retinas than in $8 \mathrm{hr}$ retinas. Likewise, optic nerves and superior colliculi contained less intact bFGF and more proteolytically clipped forms of bFGF than did retinas. An accurate estimation of the molecular weights of the proteolytically clipped forms of ${ }^{125} \mathrm{I}-\mathrm{bFGF}$ by using molecular-weight standards separated in different lanes was not possible because the differences in the amount of protein loaded resulted in significantly different rates of migration. Addition of cytochrome

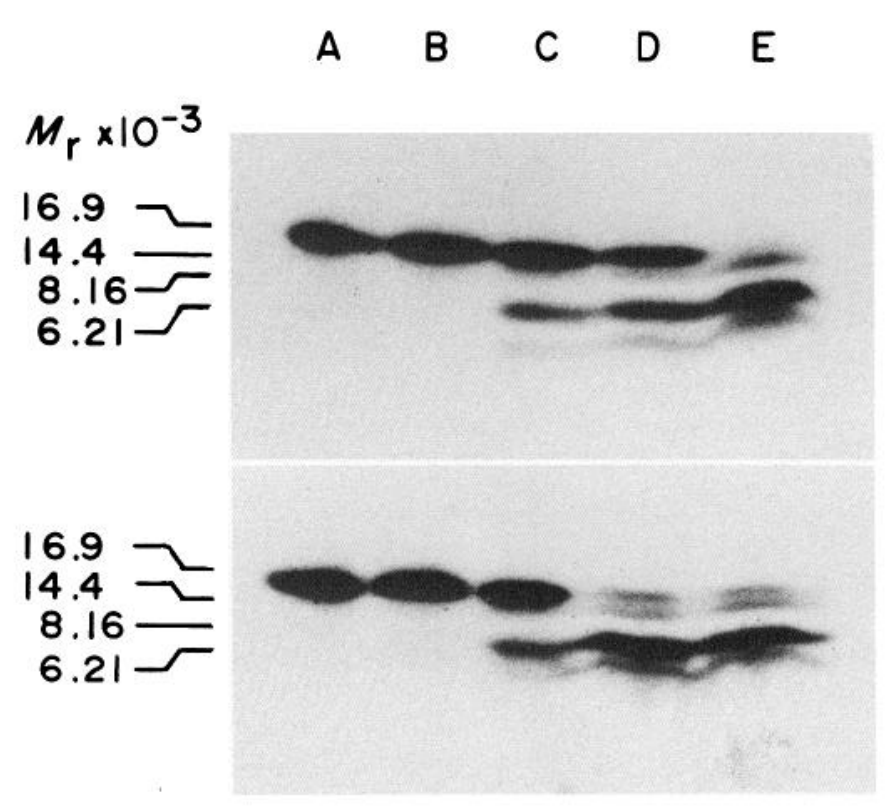

Figure 10. Intact ${ }^{125} \mathrm{I}-\mathrm{bFGF}$ and proteolytically degraded ${ }^{125} \mathrm{I}-\mathrm{bFGF}$ can be detected within the visual system. Autoradiograms (24-hr exposures) of 4-20\% gradient SDS-PAGE showing ${ }^{125} \mathrm{I}-\mathrm{bFGF}(A)$, retinas $8 \mathrm{hr}(B)$ and $18 \mathrm{hr}(C)$ after intraocular injection of ${ }^{125} \mathrm{I}-\mathrm{bFGF}$, optic nerve tissue $(D)$, and superior colliculi $(E)$ from animals injected intraocularly $18 \mathrm{hr}$ earlier with ${ }^{125} \mathrm{I}-\mathrm{bFGF}$. Tissue samples are pooled from 4 animals each, and an equivalent amount of radioactivity per lane was loaded. Upper and lower autoradiograms are from separate experiments and illustrate the degree of individual variation observed in the amounts of intact and degraded ${ }^{125}$ I-bFGF normally seen. Molecular-weight standards are obtained from a separate lane; see text for estimations of the molecular weights of the proteolytically clipped forms of ${ }^{125}$ I-bFGF.

c $(12,300 \mathrm{Da})$ and/or myoglobin-fragment cleavage products $(16,950,14,400,8160,6210$, and $2510 \mathrm{Da})$ into brain tissue samples prior to SDS-PAGE allowed the molecular weights to be estimated: the predominant proteolytically cleaved forms of ${ }^{125} \mathrm{I}-\mathrm{bFGF}$ have molecular weights of about 16,500, 10,000, and $8000 \mathrm{Da} .{ }^{125} \mathrm{I}-\mathrm{bFGF}$ has a molecular weight of $17,800 \mathrm{Da}$. These data indicate that, as intact ocular bFGF was anterogradely transported within the retinal ganglion cell, it underwent an apparently controlled proteolytic cleavage.

\section{Discussion}

\section{Axonal transport methodology}

Axonal transport methodology was used to demonstrate that the retinal ganglion cell expresses high-affinity receptors for bFGF. While tissue culture experiments have shown that bFGF acts as a neurotrophic factor for neurons largely freed from glial contamination (Unsicker et al., 1987; Walicke, 1988; Walicke and Barde, 1988) and that hippocampal neurons in culture have high- and low-affinity binding sites for bFGF (Walicke et al., 1989), direct proof of functional bFGF receptors on neurons in vivo has been lacking. The demonstration of bFGF receptors on neurons has been complicated by the absence of specific antibodies or probes for the bFGF receptor. The present studies circumvented these methodological problems by allowing the living nerve to separate receptor-bound ${ }^{125} \mathrm{I}-\mathrm{bFGF}$ from other radioactivity. This permitted the receptor-mediated internalization of bFGF and its subsequent axonal transport and metabolism to be demonstrated in vivo. 


\section{$b F G F$ and the PNS}

Specific receptor-mediated retrograde transport of ${ }^{125} \mathrm{I}-\mathrm{bFGF}$ in the peripheral motor, sensory, or sympathetic nervous system could not be demonstrated, suggesting that these neurons do not express significant numbers of functional receptors for bFGF. bFGF is reported to provide trophic support for axotomized sensory neurons innervating the sciatic nerve in vivo (Otto et al., 1987) and to enhance long-term survival of chick spinal cord neurons, including motor neurons, in culture (Unsicker et al., 1987). However, since these PNS neurons in the adult or newborn rat do not retrogradely transport bFGF from their innervated target tissue in a receptor-mediated manner, it is unlikely that $b F G F$ is acting as a target-derived trophic factor in a manner analogous to NGF. A morc plausiblc cxplanation might be that bFGF is acting indirectly, via non-neuronal cells, to promote the observed survival of axotomized, peripheral sensory neurons (Otto et al., 1987). In support of this idea, bFGF immobilized within silicone chambers promotes sciatic nerve regeneration (Danielsen et al., 1988).

\section{Neuronal bFGF receptor}

In vitro studies (Moscatelli, 1987, 1988) provide an understanding of the interrelationship between bFGF and both its highaffinity receptor and its binding to the heparin-like substances that are present on both the cell surface and in the extracellular matrix. Studies on bovine endothelial capilliary cells in vitro indicate that (1) when exogenous ${ }^{125} \mathrm{I}-\mathrm{bFGF}$ is added, it binds predominantly to the more numerous heparin-like substances, and only a small percentage of the ${ }^{125} \mathrm{I}-\mathrm{bFGF}$ binds directly to high-affinity receptors; (2) the ${ }^{125} \mathrm{I}-\mathrm{bFGF}$ that binds to highaffinity receptors is first internalized and then proteolytically clipped; and (3) as ${ }^{125} \mathrm{I}-\mathrm{bFGF}$ is removed from the environment by being internalized, new high-affinity receptors are exposed, and ${ }^{125}$ I-bFGF previously bound to heparin-like substances is mobilized, is bound to these unoccupied receptors, and is internalized. In this manner, the added ${ }^{125} \mathrm{I}-\mathrm{bFGF}$ is gradually cleared from the environment. Although the in vivo situation is considerably more complex, we obtained results by using various modulators of bFGF binding that are consistent with the process reported above. That is, while all other interpretations cannot be rigorously excluded, the data are consistent with the following scheme: (1) The eye contains substantial amounts of heparin-like substances; (2) binding and retention of the bulk of the ${ }^{125} \mathrm{I}-\mathrm{bFGF}$ within the eye is largely influenced by heparinlike binding; (3) high-affinity receptors on retinal ganglion cells mediate the internalization of bFGF; and (4) internalized bFGF undergoes axonal transport out of the eye. These findings raise the possibility that the retinal ganglion cell uptake of ocular bFGF may influence the amount of bFGF within the ocular environment.

\section{Basic FGF: a neurotrophic factor?}

The receptor-mediated axonal transport of bFGF and its derivatives raises a number of questions, the most prominent being: does this phenomenon have any physiological significance? While it is possible that bFGF has no direct trophic effects on retinal ganglion cells in vivo, bFGF has been shown to promote neuritic outgrowth in dissociated retinal ganglion cells in vitro (Lipton et al., 1988) and to enhance temporarily the survival of retinal ganglion cells in retinal explants (Bahr et al., 1989). In vivo bFGF-impregnated Gelfoam implanted next to transected optic nerve reduces the axotomy-induced degeneration of retinal ganglion cells (Sievers et al., 1987). bFGF has also been shown to act as a neurotrophic factor for various neurons in tissue culture (Walicke et al., 1986; Walicke, 1988; Ferrari et al., 1989). Thus, the finding of receptor-mediated axonal transport of bFGF and its derivatives in retinal ganglion cells might indicate that retinal ganglion cells may respond directly to $\mathrm{bFGF}$, perhaps in a manner analogous to NGF. The receptor-mediated axonal transport of NGF may be a mechanism for transferring target-derived trophic information to the cell body of the neuron (see Johnson et al., 1987, for discussion). On the other hand, it has been argued (Barde, 1987) that bFGF does not neatly fit into the classical definition of a target-derived factor essential for the long-term survival of retinal ganglion cells: retinal ganglion cell bodies lie within an environment rich in bFGF (Gospodarowicz et al., 1986), yet their population is reduced after optic nerve section (Perry, 1981). Furthermore, it would seem unlikely that bFGF could provide information on the size of the retinal ganglion cell target tissue because bFGF does not appear to be retrogradely transported in a receptor-mediated manner to the neuronal cell body from the lateral geniculate body or superior colliculus. Unlike NGF, which undergoes rapid proteolytic degradation upon axonal transport to the neuronal cell body (Johnson et al., 1978), internalized bFGF undergoes slow proteolytic clipping. This relatively slow proteolytic processing of internalized bFGF may be a phenomenon common to other cells expressing bFGF receptors. Bovine capilliary endothelial cells proteolytically process bFGF in a similar manner (Moscatelli, 1988). It remains to be determined whether these proteolytically clipped derivatives of bFGF can bind to and stimulate the bFGF receptor. $\mathrm{b} \Gamma \mathrm{G} \Gamma$ species whose amino-terminal ends have undergone varying degrees of cleavage have been shown to retain full biological activity (Moscatelli et al., 1988). If the bFCF derivatives identified within retinal ganglion cells and their terminal projections retain biological activity, then the axonal transport of internalized, receptor-bound bFGF or its derivatives may provide a mechanism for intracellular distribution of a second messenger. Furthermore, the possibility that the transported bFGF and derivatives are biologically active raises the possibility that some of this material may be released at the synaptic terminals in the superior colliculus and thus act as an anterogradely transported trophic factor. Indeed, the neurons in the superior colliculus and/or lateral geniculate body have long been known to undergo substantial anterograde degeneration after enucleation or optic nerve section, which suggests that anterograde transport of ocular trophic factors may provide trophic support for some neurons in these nuclei.

\section{Comparison of $N G F$ and $b F G F$}

Figure 11 summarizes our major findings and contrasts them with the accepted mechanism of action of NGF. NGF is shown acting on a sensory neuron of the PNS, bFGF on a retinal ganglion cell. bFGF, like NGF, binds to high-affinity receptors present on the membranes of responsive neurons. It is internalized and undergoes axonal transport at relatively similar maximum rates of transport. Unlike NGF, which is not anterogradely transported (E. M. Johnson, unpublished observations), bFGF and its derivatives are transported away from the retinal ganglion cell body. In Figure 11, it is assumed that the uptake of bFGF takes place on the dendritic processes of the retinal ganglion cell and that internalized bFGF is transported to the vicinity of the neuronal cell body before beginning its 

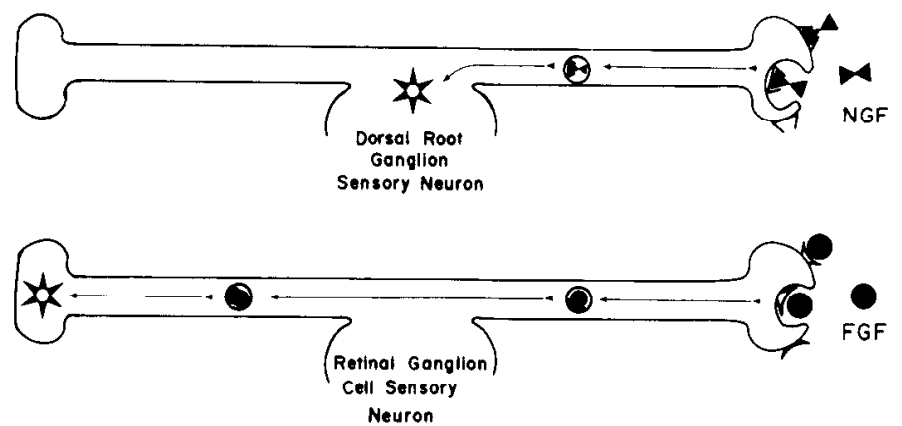

Figure 11. Comparison of axonal transport of bFGF and NGF. Like NGF, bFGF binds to high-affinity receptors on responsive neurons, is internalized, and is axonally transported. Unlike NGF, which is rapidly degraded upon reaching the neuronal cell body, bFGF is degraded more slowly and can be transported anterogradely in the retinal ganglion cell axon.

journey away from the retina. A prominent difference between NGF and bFGF appears to be the rate at which these 2 molecules are degraded. Retrogradely transported NGF is degraded very rapidly in the neuronal cell body (Johnson et al., 1978), whereas bFGF appears to undergo relatively slow and limited proteolytic cleavage. It remains to be determined whether bFGF or its derivatives can function as anterogradely transported trophic factors

\section{References}

Anderson KJ, Dam D, Lee S, Cotman CW (1988) Basic fibroblast growth factor prevents death of lesioned cholinergic neurons in vivo. Nature 332:360-361.

Bähr M, Vanselow J, Thanos S (1989) Ability of adult rat ganglion cells to regrow axons in vitro can be influenced by fibroblast growth factor and gangliosides. Neurosci Lett 96:197-201.

Barde Y-A (1987) What, if anything, is a neuronotrophic factor? TINS 11:343-346.

Bashkin P, Doctrow S, Klagsburn M, Svahn CM, Folkman J, Vlodavsky I (1989) Basic fibroblast growth factor binds to subendothelial extracellular matrix and is released by heparitinase and heparin-like molecules. Biochemistry 28:1737-1743.

Bocchini V, Angeletti PU (1969) The nerve growth factor: purification as a 30,000-molecular-weight protein. Proc Natl Acad Sci USA 64: 787-794.

Bohlen P, Esch F, Baird A, Gospodarowicz D (1985) Acidic fibroblast growth factor from bovine brain. Amino acid terminal sequence and comparison to basic fibroblast growth factor. EMBO J 4:1951-1957.

Cowan WM (1970) Anterograde and retrograde transneuronal degeneration in the central and peripheral nervous system. In: Contemporary research methods in neuroanatomy (Nauta WJH, Ebbesson SOE, eds), pp 217-251, Berlin: Springer-Verlag.

Danielsen N, Pettmann B, Vahlsing HL, Manthorpe M, Varon S (1988) Fibroblast growth factor effects on peripheral nerve regeneration in a silicone chamber model. J Neurosci Res 20:320-330.

Dreyer D, Lagrange A, Grothe C, Unsicker K (1989) Basic fibroblast growth factor prevents ontogenetic neuron death in vivo. Neurosci Lett 99:35-38.

Eccleston PA, Silberber DH (1985) FGF is a mitogen for oligodendrocytes. Brain Res 353:315-320.

Feige J-J, Baird A (1988) Glycosylation of the basic fibroblast growth factor receptor. J Biol Chem 263:14023-14029.

Ferguson IA, Schweitzer JB, Johnson FM Jr (1989) The fate of FGF in the optic tract. Soc Neurosci Abstr 15:277.

Ferrara N, Ousley F, Gospodarwicz D (1988) Bovine brain astrocytes express basic fibroblast growth factor, a neurotropic and angiogenic mitogen. Brain Res 462:223-232.

Ferrari G, Minozzi M-C, Toffano G, Leon A, Skaper SD (1989) Basic fibroblast growth factor promotes the survival and development of mesencephalic neurons in culture. Dev Biol 133:140-147.
Fox GM, Schiffer SG, Rohde MF, Tsai LB, Banks AR, Arakawa T (1988) Production, biological activity, and structure of recombinant basic fibroblast growth factor and an analog with cysteine replaced by serine. J Biol Chem 263:18452-18458.

Gensburger C, Labourdette G, Sensenbrenner M (1987) Brain basic fibroblast growth factor stimulates the proliferation of rat neuronal precursor cells in vitro. FEBS Lett 217:1-5.

Gospodarowicz D, Cheng J, Lui G-M, Baird A, Bohlen P (1984) Isolation by heparin-sepharose affinity chromatography of brain fibroblast growth factor: identity with pituitary fibroblast growth factor. Proc Natl Acad Sci USA 81:6963-6967.

Gospodarowicz D, Neufeld G, Schweigerer L (1986) Molecular and biological characterization of fibroblast growth factor, an angiogenic factor which controls the proliferation and differentiation of mesoderm and neurocetoderm derived cells. Cell Diff 19:1-17.

Gospodarowicz D, Ferrara N, Schweigerer L, Neufeld G (1987) Structural characterization and biological functions of fibroblast growth factor. Endocrinol Rev 8:95-114.

Hatten ME, Lynch M, Rydel RE, Sanchez J, Joseph-Silverstein J, Moscatelli D, Rifkin DB (1988) In vitro neurite extension by granule neurons is dependent upon astroglial-derived fibroblast growth factor. Dev Biol 125:280-289.

Imamura T, Tokita Y, Mitsui Y (1988) Purification of basic FGF receptors from rat brain. Biochem Biophys Res Commun 155:583-590.

Jeanny J-C, Fayein N, Moenner M, Chevallier B, Barritault D, Courtois $Y$ (1987) Specific fixation of bovine brain and retinal acidic and basic fibroblast growth factors to mouse embryonic eye basement membranes. Exp Cell Res 171:63-75.

Johnson EM Jr, Andres RY, Bradshaw RA (1978) Characterization of the retrograde transport of nerve growth factor (NGF) using high specific activity [125]NGF. Brain Res 150:319-331.

Johnson EM Jr, Taniuchi M, Clark HB, Springer JE, Koh S, Tayrien MW, Loy R (1987) Demonstration of retrograde transport of nerve growth factor receptor in the peripheral and central nervous system. J Neurosci 7:923-929.

Laemmli UK (1970) Cleavage of structural proteins during assembly of the head of bacteriophage T4. Nature 227:680-682.

Lee PL, Johnson DE, Cousens LS, Fried VA, Williams LT (1990) Purification and complementary DNA cloning of a receptor for basic fibroblast growth factor. Science 245:57-60.

Linden R, Perry VH (1983) Massive retinotectal projection in rats. Brain Res 272:145-149.

Lipton SA, Wagner JA, Madison RA, D'Amore PA (1988) Acidic fibroblast growth factor enhances regeneration of processes of postnatal mammalian retinal ganglion cells in culture. Proc Natl Acad Sci USA 85:2388-2392.

Marchalonis JJ (1969) An enzyme method for the trace iodination of immunoglobulins and other proteins. Biochem J 113:299-305.

Morrison RS, DeVeillis J, Lee YL, Bradshaw RA, Eng LF (1985) Hormones and growth factors induced the synthesis of glial fibrillary acidic protein in rat brain astrocytes. J Neurosci Res 14:167-172.

Morrison RS, Sharma A, DeVellis J, Bradshaw RA (1986) Basic fibroblast growth factor supports the survival of cerebral cortical neurons in primary culture. Proc Natl Acad Sci USA 83:7537-7541.

Morrison RS, Keating RF, Moskal JR (1988) Basic fibroblast growth factor and epidermal growth factor exert differential trophic effects on CNS ncurons. J Ncurosci Res 21:71-79.

Moscatelli D (1987) High and low affinity binding sites for basic fibroblast growth factor on cultured cells: absence of a role for low affinity binding in the stimulation of plasminogen activator production by bovine capillary endothelial cells. J Cell Physiol 131:123130.

Moscatelli D (1988) Metabolism of receptor-bound and matrix-bound basic fibroblast growth factor by bovine endothelial cells. J Cell Biol 107:753-759.

Moscatelli D, Joseph-Silverstein J, Presta M, Rifkin B (1988) Multiple forms of an angiogenesis factor: basic fibroblast growth factor. Biochemie 70:83-87.

Neufeld G, Gospodarowicz D (1986) Basic and acidic fibroblast growth factor interact with the same cell surface receptor. J Cell Biol 261: 5631-5637.

Otto D, Unsicker K, Grothe C (1987) Pharmacological effects of nerve growth factor and fibroblast growth factor applied to the transectioned sciatic nerve on neuron death in the adult rat dorsal root ganglia. Neurosci Lett 83:156-160. 
Otto D, Frotscher M, Unsicker K (1989) Basic fibroblast growth factor and nerve growth factor administered in Gelfoam rescue medial septal neurons after fimbria fornix transection. J Neurosci Res 22:83-91.

Paxinos G, Watson C (1982) The rat brain in stereotaxic coordinates. Sydney: Academic.

Perry VH (1981) Evidence for an amacrine cell system in the ganglion cell layer of the rat retina. Neuroscience 6:931-944.

Rydel RE, Greene LA (1987) Acidic and basic fibroblast growth factors promote stable neurite outgrowth and neuronal differentiation in cultures of PC12 cells. J Neurosci 7:3639-3653.

Schubert D, Ling N, Baird A (1987) Multiple influences of a heparinbinding growth factor on neuronal development. J Cell Biol 104:635643.

Schwab ME, Thoenen H (1983) Retrograde axonal transport. In: Handbook of neurochemistry: vol 5, metabolic turnover in the nervous system (Lajtha A, ed), pp 381-404. New York: Plenum.

Sefton AJ, Dreher B (1985) Visual system. In: The rat nervous system: vol 1, forebrain and midbrain (Paxinos G, ed), pp 169-221. Sydney: Academic.

Sievers J, Hausmann B, Unsicker K, Berry M (1987) Fibroblast growth factors promote the survival of adult retinal ganglion cells after transection of the optic nerve. Neurosci Lett 76:157-162.

Togari A, Dickens G, Kuzuya H, Guroff G (1985) The effect of fibroblast growth factor on PC12 cells. J Neurosci 5:307-316.
Unsicker K, Reichart-Preibsch H, Schmidt R, Pettmann B, Labourdette $G$, Sensenbrenner M (1987) Astoglial and fibroblast growth factors have neuronotrophic functions for cultured peripheral and central nervous system neurons. Proc Natl Acad Sci USA 84:5459-5463.

Wagner JA, D'Amore PA (1986) Neurite outgrowth induced by an endothelial cell mitogen isolated from retina. J Cell Biol 103:1363$136 \%$.

Walicke PA (1988) Basic and acidic fibroblast growth factors have trophic effects on neurons from multiple CNS regions. J Neurosci 8: $2618-2627$.

Walicke PA, Baird A (1988) Neurotrophic effects of basic and acidic fibroblast growth factors are not mediated through glial cells. Dev Brain Res 40:71-79.

Walicke P, Cowan MW, Ueno N, Baird A, Guillemin R (1986) Fibroblast growth factor promotes survival of dissociated hippocampal neurons and enhances neurite extension. Proc Natl Acad Sci USA 83:3012-3016.

Walicke P, Feige J-J, Baird A (1989) Characterization of the neuronal receptor for basic fibroblast growth factor and comparison to receptors on mesenchymal cells. J Biol Chem 264:4120-4126.

Yan Q, Snider WD, Pinzone JJ, Johnson EM Jr (1988) Retrograde transport of nerve growth factor (NGF) in motoneurons of developing rats: assessment of potential neurotrophic effects. Neuron 1:335-343. 